INITIAL RESULTS OF A 2D BURIAL/THERMAL HISTORY MODEL, CENTRAL APPALACHIAN BASIN, OHIO AND WEST VIRGINIA

\author{
E. L. Rowan \\ R. T. Ryder \\ J. E. Repetski \\ M. H. Trippi \\ L. F. Ruppert \\ U. S. Geological Survey \\ 12201 Sunrise Valley Drive \\ Reston, VA 20192
}

U.S. Geological Survey Open File Report 2004-1445 


\title{
INITIAL RESULTS OF A 2D BURIAL/THERMAL HISTORY MODEL, CENTRAL APPALACHIAN BASIN, OHIO AND WEST VIRGINIA
}

\begin{abstract}
A preliminary model of burial/thermal history and hydrocarbon generation is presented for a regional-scale $(354 \mathrm{~km})$ geologic cross section oriented approximately perpendicular to the Appalachian basin axis. The section extends through relatively undeformed strata, from the Rome trough in central West Virginia, northwestward to the Findlay arch in northwestern Ohio. The model incorporates sedimentation, compaction, uplift, and erosion, and assumes a constant basement heat flow of $60 \mathrm{~mW} / \mathrm{m}^{2}$. Relatively low thermal conductivities are assigned to coals $\left(0.2 \mathrm{~W} / \mathrm{m}^{\circ} \mathrm{C}\right)$ and to kerogen-rich black shales $\left(0.9 \mathrm{~W} / \mathrm{m}^{\circ} \mathrm{C}\right)$. Thermal maturity measurements of conodont color alteration index (CAI) and vitrinite reflectance (Ro\%) from Ordovician, Devonian, and Pennsylvanian rocks constrain the model. Even with the low thermal conductivities, the model requires the deposition of additional Permo-Triassic sediment, subsequently removed by erosion, in order to match measured thermal maturity values. In this model, maximum burial is assumed to have occurred at the end of the Middle Triassic (230 m.y.), with deposition of a wedge of Permo-Triassic sediment. The added sediment is $7200 \mathrm{ft}(2195 \mathrm{~m})$ thick at the southeast end of the section, thins to the northwest, and pinches out at the western margin of the basin. The additional, modeled, Permo-Triassic sediment is completely eroded by present day, leaving only the current, measured formation thicknesses.
\end{abstract}

An important goal of the study is to predict the timing of thermal maturation of key hydrocarbon source rocks. We present calculations for two source rock intervals, Middle - Upper Devonian shales and the Ordovician Utica Shale. The Devonian shales have generated predominantly gas and lesser amounts of oil. These hydrocarbons are trapped in sandstones of Devonian and Mississippian age as well as in fractured intervals of Devonian shale. The Utica Shale is a 100-200 ft (30-60 m) thick, laterally extensive, source rock that generated petroleum that is now trapped in Cambrian - Silurian carbonates and sandstones. 


\section{INTRODUCTION}

Substantial remaining resources of coal, oil, and gas have been attributed to the Appalachian basin (de Witt and Milici, 1989; Milici et al., 2003). The burial/thermal history model presented here is intended to further understanding of the processes that formed the basin's energy resources and ultimately to aid in developing improved exploration models. This paper reports on progess to date in our burial and thermal modeling studies of the central Appalachian basin.

The model we present is based on a recently published regional geologic cross section, (Ryder et al., 2004). The model cross section extends $354 \mathrm{~km}$, from the Rome trough in central West Virginia to the Findlay arch in northwestern Ohio, and is based on the detailed stratigraphy compiled by Ryder et al. (2004) at twelve wells (Figure 1). While our model ends within the relatively undeformed rocks of the Rome trough, the cross section of Ryder et al. (2004) extends farther southeast into the fold and thrust belt of West Virginia. Although it is possible to model thermal history within a fold and thrust belt, it requires structural reconstruction that is beyond the scope of this study. Nevertheless, our cross section traverses many of the important oil and gas fields of Ohio and West Virginia. The major oil and gas fields in Cambrian - Silurian reservoir rocks in the study area are shown in Figure 2.

The model incorporates sedimentation, compaction, uplift, and erosion. Relatively low thermal conductivities are assigned to Pennsylvanian coals $\left(0.2 \mathrm{~W} / \mathrm{m}^{\circ} \mathrm{C}\right)$ and to kerogenrich black shales $\left(0.9 \mathrm{~W} / \mathrm{m}^{\circ} \mathrm{C}\right)$ based on field and laboratory studies (Cercone et al., 1996; Gerlach and Cercone, 1993). Coal and black shale act as a thermally insulating blanket and have the potential to increase thermal gradients and thermal maturities significantly (Pollack and Cercone, 1994). To match the measured thermal maturity data, the model includes the deposition of a wedge of Permo-Triassic sediments, thickest over the Rome trough, and thinning to the northwest and the Findlay arch. The model also specifies that maximum burial occurred at the close of the Middle Triassic and was followed by erosion (Ryder and Zagorski, 2003).

Thermal maturity was constrained primarily by vitrinite reflectance $\left(\mathrm{R}_{0} \%\right)$ measurements on Pennsylvanian coals (Cole et al., 1979; Chyi et al., 1987; L. F. Ruppert, USGS unpub. data) and color alteration index (CAI) values measured in conodonts in Devonian and Ordovician limestones (Repetski et al., 2002; 2004; in review; USGS unpub. data). It has long been noted that these Ro and CAI values require significantly greater temperatures than recorded today (e.g., Epstein et al., 1977). In the model, we achieve the required temperature range by reconstructing burial by strata now removed by erosion. PermoTriassic sediments comprise the largest component of the reconstructed sediments. The model also includes comparatively minor reconstruction of Pennsylvanian strata and of the Mississippian - Silurian strata that were eroded over the Findlay arch.

Groundwater circulation and advective heat transport have also been proposed as a mechanism for elevating temperatures and thermal maturities (e.g., Carlson, 1994; Evans, 1995, Evans and Hobbs, 2003; Harrison et al., 2004). This model examines the effects of 
burial alone, to determine where the available fluid inclusion, CAI, and Ro\% measurements can be explained by simple burial. Where burial cannot account for temperatures and maturities, paleo-groundwater circulation is likely to have played a role in the thermal history.

Our model incorporates the results of several recent studies (e.g., Cercone et al., 1996; Repetski et al., 2004; Ryder et al., 2004) in an attempt to provide a new and more accurate estimate of 1) post-Pennsylvanian burial history, (i.e., the thickness of the section deposited and subsequently eroded), and 2) the temperatures and pressures associated with this burial history, and 3) the timing and degree of kerogen maturation in key hydrocarbon source rocks. A burial history model calibrated with thermal maturity data, permits us to track the evolution of temperature and pressure through time, and serves as a starting point and framework for further investigation of hydrocarbon phase behavior. For example, oil may crack to gas or gas may dissolve in groundwater due to increased temperature and pressure with progressive burial; gas may exsolve from groundwater or condense to liquid with decreased pressure caused by uplift and erosion. The enigmatic "basin-centered gas" accumulations, examples of which occur in the central Appalachian basin (Ryder and Zagorski, 2003), could best be studied in the context of a model that provides reliable temperatures and pressures through time.

\section{MODEL ASSUMPTIONS \& PARAMETERS}

\section{Model Grid and Calculations}

The stratigraphy of the model consists of 16 units representing groups of formations. The individual formation tops and thicknesses were determined by Ryder et al. (2004) in 12 wells, from geophysical and lithologic logs (Tables 1 and 2). Grid cell widths are 2.8 $\mathrm{km}$, and cell heights are a maximum of $280 \mathrm{~m}$, with a minimum of three cells per model unit. Fluid pressure, sediment compaction, heat flow, and thermal maturation equations

were solved over the finite difference grid shown in Figure 3. Hydrostatic pressures and conductive heat flow were assumed for this model.

\section{Heat Flow and Surface Temperature}

Basement heat flow in the model was specified to be $60 \mathrm{~mW} / \mathrm{m}^{2}$ and constant through time. We used the heat flow value assumed by Cercone et al. (1996) in a study of the Appalachian basin in western Pennsylvania. These authors derived their heat flow assumption from the results of a literature search for the region. Our model does not include high heat flow associated with formation of the Lower - Middle Cambrian Rome trough. The elevated heat flow associated with crustal extension and rifting would likely have decayed to present day values before the rift basin was completely filled. By the close of Middle Cambrian time the Rome trough basin was no longer a depocenter and cannot be detected on our cross section by thickening of strata (Ryder et al., 2004). High heat flows associated with the Rome trough would have affected the thermal maturities of 
Middle Cambrian and older strata, however, the focus of this study is on the maturities of the Ordovician Utica Shale and younger hydrocarbon source rocks and coals. The Mesozoic rift basins that formed along the eastern margin of the U.S. are considered too distant to have affected heat flow in our model.

Paleo-surface temperatures for the model were obtained from a compilation of ocean surface temperatures and their variation with latitude and through time (Wygrala, 1989; data from Frakes, 1979; reproduced in Poelchau et al., 1997, Fig. 1.5). A present day surface temperature of $13^{\circ} \mathrm{C}$ is used, based on mean annual temperature data reported in Hulver (1997, p. 921).

\section{Lithologies and their Properties}

The lithologies of each model unit were defined using lithologic logs compiled by the Geological Sample Log Company. These logs were available for nine of the twelve wells on the cross section (Table 1). The unusual wealth of detail provided by these logs was quantified with the aid of LITHOS, a macro-based spreadsheet utility (D. O. Hayba, USGS, written comm., 2004) that facilitates the translation of lithologic logs to digital form. The precision of the log-derived lithologic fractions far exceeds their probable accuracy. Within model units, the lithologic proportions showed large variations with no discernable trend along the cross section. A certain amount of the variation must be due to the fact that the wells were logged over a 20+ year time span, presumably by different people. We chose to average lithologic fractions between wells to smooth the variations (Table 3). Uniform lithology within each model unit results in near-uniform thermal conductivities and thermal gradients, making the interpretation of model-predicted temperatures easier.

Within each model unit, physical properties such as porosity and thermal conductivity are based on the proportions of end-member lithologies (e.g., pure sandstone), defined using LITHOS and the lithologic logs. The following seven lithologies are defined in the model: sandstone, siltstone, shale, black shale, coal, carbonate, and anhydrite. The lithologic logs made distinctions between 'black shale' and gray, brown and other shale types. We preserved the 'black shale' distinction and lumped all other shale types as ordinary 'shale' for purposes of defining lithologic properties.

Compaction (porosity-depth) curves were defined for the model using the equation:

$$
\phi=\phi_{0} \mathrm{e}^{(-\mathrm{bZ})}+\phi_{1}
$$

where $\phi=$ porosity, $\phi_{0}=$ initial porosity at deposition, $\phi_{1}=$ irreducible porosity, $Z=$ burial depth (km) and b is a lithology-specific coefficient (Table 4; Bethke et al., 1991). The earliest reference to an equation of this form is, to our knowledge, Athy (1930), although he did not include the term for irreducible porosity. Values used to define the compaction curves of coal and anhydrite were obtained from parameters tabulated in the 
PetroMod software package. For the remaining five lithologies we used parameters tabulated by Bethke et al. (1991) for the Illinois basin (Table 4).

The water content (i.e., porosity) of a rock exerts a primary control on bulk thermal conductivity due to the large contrast between the conductivities of water and most minerals. The thermal conductivity of water is $0.6 \mathrm{~W} / \mathrm{m}^{\circ} \mathrm{C}$ compared with values of $0.9-$ $4.2 \mathrm{~W} / \mathrm{m}^{\circ} \mathrm{C}$ for all of the model lithologies other than coal. Coals have exceptionally low thermal conductivities; the value used in this study is $0.2 \mathrm{~W} / \mathrm{m}^{\circ} \mathrm{C}$, based on the work of Pollack and Cercone, (1994). Bulk thermal conductivity $(\lambda)$ is computed in this study using the equation:

$$
\lambda=\mathrm{A} \phi+\mathrm{B}
$$

where $\mathrm{A}$ is a lithology-specific coefficient, and $\mathrm{B}=$ conductivity of the mineral matrix at zero porosity (Bethke et al., 1991). Thermal conductivity values for kerogen-rich black shales, as well as coals, were obtained from Cercone et al. (1996). Thermal conductivities of shale, siltstone, sandstone and carbonate were obtained from a study of the Cherokee basin (Förster et al., 1998), and for anhydrite, we used the value tabulated in the PetroMod software package (Table 4). Figure 4 shows a profile of the bulk thermal conductivity (i.e., rock plus water) for each model unit in the McCoy well (\#11). This well was selected as an example because it contains a comprehensive stratigraphic section from Permian to Precambrian basement.

\section{Timing of Maximum Burial}

Peak uplift east of the Appalachian basin occurred near the close of the Pennsylvanian period, and subsequent erosion provided the thick wedge of post-Pennsylvanian sediments that filled the foreland basin to the west. The model assumes that maximum burial occurred at 230 m.y., at the end of the Middle Triassic (Ryder and Zagorski, 2003), and was followed by erosion at a steady rate until present day. Figure 5 shows the model cross section at present day, including topography.

\section{MODEL RESULTS}

\section{Reconstruction of Eroded Section}

One of the goals of the model is to estimate the thickness of the strata that have been removed by erosion. A wedge of Permian through Middle Triassic sediments comprises the bulk of the reconstructed sediments. The dimensions of the wedge were adjusted so as to match the vitrinite reflectance and conodont CAI thermal maturity constraints. PermoTriassic sediments in the model are $7200 \mathrm{ft}(2195 \mathrm{~m})$ thick at the southeast end of the section (Gainer Lee well, \#12), thin to the northwest, and pinch out at the Palmer well (\#6) (Figure 6, Table 5). 
The model also includes a simple reconstruction of the Pennsylvanian through Silurian strata; they were assumed to maintain their northwest thinning trends, but with continuous deposition over the Findlay arch (Figure 6). Moderate amounts (572-1260 ft; 174-384 m) of Pennsylvanian sediment were reconstructed between the Ullman well (\#9) and the northwest end of the section. Relatively minor thicknesses (330-720 ft; 101-220 m) of Mississippian - Silurian strata were reconstructed over the Findlay arch (Figure 6; Table 5).

\section{Thermal Maturity Constraints}

Thermal maturities calculated by the model are plotted for comparison with four sets of thermal maturity constraints: 1) measurements of vitrinite reflectance in Pennsylvanian coals, 2) reflectance measurements on dispersed vitrinite in Devonian shales, 3) conodont CAI measurements in Devonian carbonates and 4) conodont CAI measurements in Ordovician carbonates (Figures 7-10).

Vitrinite Reflectance in Pennsylvanian Coals

Vitrinite reflectance (Ro\%) data from Pennsylvanian coals (Chyi et al., 1987; L. F. Ruppert, USGS unpub. data) are available only for the southeastern half of the cross section, because these rocks have been eroded to the northwest (Figure 5). The ranges of model-calculated Ro\% values from base to top of the Pennsylvanian model unit are shown in parentheses for wells 7-12 (Figure 7). In the Lee well (\#7), where the Pennsylvanian rocks have been removed by erosion both in the model and in reality, model values were obtained by stepping back in time to 20 m.y. before present to obtain the Ro\% value before that layer was stripped away.

Vitrinite Reflectance in Devonian Shales

Vitrinite reflectance (Ro\%) measurements have been made on dispersed vitrinite in the Upper Devonian Rhinestreet Shale and Middle Devonian Marcellus Shale and their equivalents (Repetski et al., 2002; in review; USGS unpub. data). These data were compared with calculated Ro\% values at the base of the 'Devonian - lower shales' model unit (see Table 2 for formations included in each model unit). The measured Ro\% values are significantly lower than values predicted by the model (Figure 8). For example, the model predicts Ro\% values of 1.5 to 2.2 at wells $10-12$, whereas the data in the vicinity of these wells range from 0.7 to 1.6 .

We speculate that reflectances of these Devonian vitrinites may be suppressed, like the those of the Upper Devonian - Lower Mississippian New Albany Shale in Illinois, Indiana, and Kentucky (Nuccio and Hatch, 1996). The New Albany Shale is approximately equivalent stratigraphically to the Devonian Appalachian basin shales sampled by Repetski et al. (in review; USGS unpub. data). Although the mechanisms causing vitrinite reflectance suppression are not well understood, Nuccio and Hatch (1996) noted that the degree of suppression was correlated with the hydrogen content (hydrogen index) and maturation level of their samples. A recent study has shown also 
that vitrinite reflectance can vary with the composition of the vitrinite in marinedeposited rocks (Ujiié et al., 2004).

Variability in the type of organic matter might explain the occasionally erratic pattern of Ro\% values. For example, values of 0.51 and 0.88 , or 0.56 and 1.03 , have been measured at sites less than 25 miles $(40 \mathrm{~km})$ apart, where burial histories would be expected to be similar (see Figure 8, West Virginia, southernmost portion of the map). In several localities in eastern Ohio, Ro\% values decrease (rather than increase) with depth from the Pennsylvanian coals to the Devonian shales. Given the apparent liklihood of vitrinite reflectance suppression, we did not alter the model to attempt or match the Ro\% measurements made in the Devonian shales.

Conodont CAI in Devonian and Ordovician Rocks

Conodont color alteration index (CAI) data were provided by Repetski et al. (2002; 2004; in review; USGS unpub. data) for the Devonian Onondaga Limestone, and for the Ordovician Trenton-Black River Limestone and equivalent units. The conodonts chosen for CAI determination were limited to those extracted from carbonate rocks. Conodonts found in organic-rich black or dark shales have lower CAI values than those from carbonate rocks in the same stratigraphic succession. Laboratory experiments by Epstein et al. (1977) and Rejebian et al. (1987) showed that conodonts heated in closed methanewater systems, i.e., in conditions similar to those in low-permeability shales, have suppressed CAI values compared to those heated in open systems and in the absence of an organic-rich microenvironment.

In order to compare model-predicted thermal maturities with conodont CAI data, Ro\% values were translated to equivalent CAI values using the correlation equation of Hulver (1997, Equation 3.21, p. 99). The equation is a continuous function whose results we discretized such that values between 2.0 and 2.49 were given a CAI value of 2, values between 2.5 and 2.99 a value of 2.5 etc, consistent with the methodology of Epstein et al. (1977). Although Hulver (1997) found a good correlation between Ro\% and CAI in the data he examined $\left(r^{2}=0.934\right)$, the variation in the data is large. Neither the actual data nor standard deviations were reported, but it is likely that for a given CAI value an uncertainty of one sigma in the corresponding Ro\% would be at least 1.0\% Ro.

The range of calculated conodont CAI values from base to top of the Onondaga Limestone in wells 4-12 match well with the data (Figure 9). However, in wells 1-3, on the Findlay arch, the Onondaga Limestone has been stripped away by erosion. A similar comparison was made between data and calculated conodont CAI values for the 'Ordovician Trenton-Black River' model unit, again with good agreement (Figure 10). Ordovician strata are present over the entire cross section. Uncertainties and error bars were not included in our comparisons of calculated with measured values. 


\section{DISCUSSION}

\section{Timing of Thermal Maturation}

An important goal of the model is the ability to predict the timing of thermal maturation of oil and gas source rocks, based on their burial and thermal history. The model makes it possible to compute temperatures at any point in the grid (Figure 3) and through time. We provide examples below from two of the Appalachian basin's major hydrocarbon source rock intervals, the Ordovician Utica Shale, and the Middle and Upper Devonian shales. This approach can be applied to any source rock within the modeled section, and could be refined using formation-specific kerogen kinetics, rather than vitrinite reflectance, to define thermal maturity.

\section{Ordovician Utica Shale}

The thermal maturity of the Ordovician Utica Shale (defined in terms of Ro\%) is plotted at six time horizons over the length of the cross section (Figure 11). This plot shows the the Utica entered the oil window during the Late Devonian in the Rome trough $(350 \mathrm{~km}$ on the cross section, Figure 5). In the distal part of the basin (100 km on the cross section, Figure 5), the Utica entered the oil window at maximum burial at the end of the Middle Triassic (230 m.y.). On the Findlay arch and its eastern flank (wells 1-4), the model predicts that the Utica Shale is still immature at present day (Ro\% $<0.6$; Figure 11).

Middle - Upper Devonian Shales

A set of plots similar to those described for the Utica Shale was constructed for three horizons within the thick interval of Devonian shales: 1) the top of the Onondaga Limestone (Middle Devonian, model top age of 390 m.y.), equivalent to the base of the Devonian shale interval, 2) the base of the Ohio Shale (Upper Devonian, model top age of 377 m.y.), and 3) the top of the Ohio Shale (Upper Devonian, model top age of 360 m.y.), (Table 2; Figures 12A-C). The model indicates that by the close of the Mississippian (325 m.y.), the base of the Devonian shale section over approximately a third of the the cross section $(230-360 \mathrm{~km})$ was in the oil window, and at present, is in the gas window. To the northwest, on the flank of the Findlay arch, this horizon is immature even at present day (Figure 12A).

The top of the Ohio Shale (i.e., the top of the Devonian shale interval), was immature $(\mathrm{Ro}<0.5 \%)$ at the close of the Pennsylvanian, but entered the oil window during PermoTriassic burial reconstructed by the model (Figure 12C). The timing of thermal maturation at the base of the Ohio Shale, a horizon that occupies an intermediate position in the Devonian shale interval, is shown in Figure 12B.

\section{Fluid Inclusion Studies}

Several fluid inclusion studies in the literature provide temperature data that we have compared with temperatures predicted by our model. Homogenization temperatures 
ranging from $62^{\circ}$ to $148^{\circ} \mathrm{C}$ have been reported for fluid inclusions in vein minerals in Middle Devonian shales from western Pennsylvania and West Virginia (Figure 13; Evans, 1995; Evans and Hobbs, 2003). Although our model of maximum burial differs in many details from that of Evans (1995), both models predict that temperatures at or near maximum burial were sufficient to account for the fluid inclusion temperatures in the Appalachian Plateau (Figure 14A, B). In constrast, in the Valley and Ridge province, beyond the southeast end of our cross section, fluid inclusions with much higher homogenization temperatures $\left(160^{\circ} \mathrm{C}\right.$ to $\left.>220^{\circ} \mathrm{C}\right)$ likely trapped syn-orogenic fluids expelled from the fold and thrust belt during Alleghenian deformation (Evans and Hobbs, 2003; Evans, 1995).

Carlson (1994) studied fluid inclusions in epigenetic fluorite and sphalerite from Devonian - Silurian dolomites on the Findlay arch (Figure 13). The interval sampled includes the Silurian Lockport Dolomite and extends upwards into the Middle Devonian Detroit River Group. The median homogenization temperatures of fluid inclusion populations from different paragenetic stages and sample sites on the arch ranged from $65.2^{\circ}$ to $121.7^{\circ} \mathrm{C}$. Even at maximum burial, our model predicts much lower temperatures (near $50^{\circ} \mathrm{C}$ ) for the Lockport Dolomite over the Findlay arch (Figure 15). Simple burial, as set forth in the model, cannot account for Carlson's fluid inclusion temperatures. Circulation of warm groundwater associated with the late Pennsylvanian Alleghenian orogeny is the most probable explanation for the anomalously warm temperatures on the Findlay arch (Carlson, 1994).

Over most of our cross sectional model, temperatures associated with burial plausibly account fluid inclusion temperatures. Groundwater flow on a regional scale is not precluded by this observation, however, the study by Evans (1995) suggests that a conductive thermal regime prevailed in the central Appalachian basin. Only near the crest of the Findlay arch do fluid inclusion temperatures appear to require advective heat transport by groundwater circulation. It is not known whether this flow occurred on a regional scale through porous aquifers, or was more localized, for example, by fractures. The predicted thermal maturities of the Utica Shale and Devonian shales are in qualitative agreement with observations drawn from outcrops, drill cuttings and core, and the burial model we present here appears valid over most of its extent. However, the model does not address fluid flow and thus may underestimate thermal maturity on the Findlay arch in localities affected by fluid flow.

\section{SUMMARY}

Sediments removed by Mesozoic - present day erosion were reconstructed in the modeled cross section as a northwest thinning wedge, $7200 \mathrm{ft}(2195 \mathrm{~m})$ thick at the southeast end, and pinching out at the northwest margin of the basin. The reconstructed sediment wedge combined with other model parameters such as heat flow, porosities, and matrix thermal conductivities, produces a reasonable match between measured and calculated thermal maturity values in Pennsylvanian, Devonian, and Ordovician rocks. 
The model incorporated the thermal conductivity values determined by Cercone et al. (1996) for coal and black shale in Pennsylvanian rocks of western Pennsylvania. These values, low relative to the conductivities of other lithologies in the model, produced corresponding high thermal gradients, thereby reducing the thickness of sediment needed to match thermal maturity data.

According to the model, the Ordovician Utica Shale began generating hydrocarbons in the Rome trough near the end of the Late Devonian. The zone of hydrocarbon generation did not extend beyond the western margin of the Rome trough until the Pennsylvanian. To the northwest, on the flank of the Findlay arch, the Utica Shale did not reach sufficient maturity to generate hydrocarbons until the Permian and, according to the model, the Utica is still immature over the crest of the Findlay arch.

In the deepest portion of the basin, according to the model, Devonian shales entered the oil window as early as the close of the Mississippian, and much of this deep interval is in the gas window today. In the deepest portion of the basin, even the top of the Devonian shale interval is in the oil window today. As with the Utica Shale, model-predicted Ro\% values for the Devonian shales fall to below 0.6\% approaching the Findlay arch.

\section{ACKNOWLEDGEMENTS}

We sincerely thank W. M. Burns and C. S. Swezey for their reviews of the manuscript.

\section{REFERENCES}

Athy, L.F., 1930, Density, porosity, and compaction of sedimentary rocks: AAPG Bulletin, v. 14, p. 1-24.

Bethke, C.M., Reed, J.D., and Oltz, D.F., 1991, Long-range petroleum migration in the Illinois basin, in Leighton, M.W., Kolata, D.R., Oltz, D.F., Eidel, J.J., ed., Interior Cratonic Basins, Memoir 51, Ch. 26: Tulsa, Oklahoma, American Association of Petroleum Geologists, p. 455-472.

Carlson, E.H., 1994, Geologic, fluid inclusion, and isotopic studies of the Findlay Arch District, Northwestern Ohio: Economic Geology, v. 89, p. 67-90.

Cercone, K.R., Deming, D., and Pollack, H.N., 1996, Insulating effect of coals and black shales in the Appalachian basin, western Pennsylvania: Organic Geochemistry, v. 24, no. 2, p. 243-249.

Chyi, L.L., Barnett, R.G., Burford, A.E., Quick, T.J., and Gray, R.J., 1987, Coalification patterns of the Pittsburgh coal: their origin and bearing on hydrocarbon maturation: International Journal of Coal Geology, v. 7, p. 69-83.

Cole, G.A., Williams, D.A., and Smith., C.J., 1979, Regional coalification patterns for the 
coals of eastern Kentucky, West Virginia, Ohio, Maryland, and southern Pennsylvania, West Virginia Geological Survey Open File Report 57, 28p.

de Witt, W., and Milici, R.C., 1989, Energy resources of the Appalachian orogen, in Hatcher, R.D., Jr., Thomas, W.A., and Viele, G.W., ed., The Geology of North America, Vol. F-2, The Appalachian-Ouachita Orogen in the United States, The Geological Society of America, p. 495-510.

Epstein, A.G., Epstein, J. B., and Harris, L., 1977, Conodont color alteration -- an index to organic metamorphism: U.S. Geological Survey Professional Paper 995, 27 p.

Evans, M.A., 1995, Fluid inclusions in veins from the Middle Devonian shales: A record of deformation conditions and fluid evolution in the Appalachian Plateau: Geological Society of America Bulletin, v. 107, no. 3, p. 327-329.

Evans, M.A., and Hobbs, G.C., 2003, Fate of 'warm' migrating fluids in the central Appalachians during the Late Paleozoic Alleghenian orogeny: Journal of Geochemical Exploration, v. 78-79, p. 327-331.

Förster, A., Merriam, D.F., and Hoth, P., 1998, Geohistory and Thermal Maturation in the Cherokee Basin (Mid-Continent, U.S.A.): Results from Modeling: AAPG Bulletin, v. 82, p. 1673-1693.

Frakes, L.A., 1979, Climates throughout geological time: Amsterdam, Elsevier, 310 p.

Gerlach, J.B., and Cercone, K. R., 1993, Former Carboniferous overburden in the northern Appalachian basin: a reconstruction based on vitrinite reflectance: Organic Geochemistry, v. 20, p. 223-232.

Gradstein, F.M., Ogg, J.G., Smith, A.G., Bleeker, W., Lourens, L.J., 2004, A new geologic time scale, with special reference to Precambrian and Neogene: Episodes, v. 27, p. 83-100.

Harrison, M.J., Marshak, S., and Onasch, C.M., 2004, Stratigraphic control of hot fluids on anthracitization, Lackawanna synclinorium, Pennsylvania: Tectonophysics, v. 378, p. 85-103.

Hulver, M.L., 1997, Post-orogenic evolution of the Appalachian mountain system and its foreland: Chicago, Illinois, University of Chicago, Ph.D. dissertation, 1055 p.

Milici, R.C., Ryder, R.T., Swezey, C.S., Charpentier, R.R., Cook, T.A., Crovelli, R.A., Klett, T.R., Pollastro, R.M., and Schenk, C.J., 2003, Assessment of undiscovered oil and gas resources of the Appalachian Basin province, 2002: U.S. Geological Survey Fact Sheet FS-009-03, 2 p.

Nuccio, V.F., and Hatch, J.R., 1996, Vitrinite reflectance and selected Rock-Eval data used to identify vitrinite reflectance suppression in the Upper Devonian-Lower Mississippian New Albany Shale, Illinois basin, Indiana, and Kentucky: U.S. 
Geological Survey Open File Report 96-665, 37 p.

Poelchau, H.S., Baker, D.R., Hantschel, T., Horsfield, B., and Wygrala, B., 1997, Basin simulation and design of the conceptual basin model, in Welte, D.H., Horsfield, B., and Baker, D.R., ed., Petroleum and Basin Evolution: New York, SpringerVerlag, Chapter 1, p. 3-70.

Pollack, H.N., and Cercone, K. R., 1994, Anomalous thermal maturities caused by carbonaceous sediments: Basin Research, v. 6, p. 47-51.

Rejebian, V.A., Harris, A.G., and Huebner, J.S., 1987, Conodont color and textural alteration: An index to regional metamorphism, contact metamorphism, and hydrothermal alteration: Geological Society of America Bulletin, v. 99, p. 471479.

Repetski, J.E., Ryder, R.T., Harper, J.A., and Trippi, M. H., 2002, Thermal maturity patterns (CAI and \%Ro) in the Ordovician and Devonian rocks of the Appalachian basin in Pennsylvania: USGS Open File Report 02-302, 57 p.

Repetski, J.E., Ryder, R.T.,Weary, D.J., and Trippi, M.H., 2004, Thermal maturity patterns for Ordovician and Devonian rocks of the central Appalachian basin, based on CAI and \%Ro: Geological Society of America Abstracts with Programs, v. 36, no. 2, p. 147.

Repetski, J.E., Ryder, R.T., Avary, K. L., and Trippi, M. H., Thermal maturity patterns (CAI and \%Ro) in the Ordovician and Devonian rocks of the Appalachian basin in West Virginia: U.S. Geological Survey Open File Report, in review.

Ryder, R.T., and Zagorski, W.A., 2003, Nature, origin, and production characteristics of the Lower Silurian regional oil and gas accumulation, central Appalachian basin, United States: AAPG Bulletin, v. 87, no. 5, p. 847-872.

Ryder, R.T., Swezey, C.S., Crangle, R.D., and Trippi, M.H., 2004, Geologic cross section through the Appalachian basin from the Findlay arch, northwestern Ohio, to the Allegheny structural front, eastern West Virginia: 2004 Eastern Section AAPG Meeting, Columbus Ohio, October 3 -5, 2004. http://www.searchanddiscovery. com/documents/abstracts/2004eastern/ryder.htm.

Ujiié, Y., Sherwood, N., Faiz, M., Wilkins, R.W. T., 2004, Thermal maturity and suppressed vitrinite reflectance for Neogene source rocks of Japan: AAPG Bulletin, v. 88, p. 1335-1356.

Wygrala, B.P., 1989, Integrated study of an oil field in the southern Po basin, northern Italy: Ph.D. dissertation, Köln University: Jülich, Research Centre Jülich, Jul-Rep. 2313, ISSN 0366-0885, 217p. 
Table 1. Location and other information for wells used in constructing the model. Well data are from Ryder et al. (2004).

\begin{tabular}{|c|c|c|c|c|c|c|c|c|}
\hline Model Well No. & Short Name & Lease Name & State & County & Latitude & Longitude & API (from State) & Lithologic Log Available \\
\hline 1 & Carter & Carter & Ohio & Wood & 41.41492 & -83.60898 & $34-173-20237$ & yes \\
\hline 2 & Kerbel & Paul Kerbel & Ohio & Sandusky & 41.43770 & -83.31652 & $34-143-20147$ & yes \\
\hline 3 & Asphalt & $M$ and B Asphalt Co. & Ohio & Seneca & 41.22640 & -83.19891 & $34-147-60840$ & no \\
\hline 4 & Leonhardt & VE Leonhardt & Ohio & Crawford & 40.90996 & -82.88333 & $34-033-20050$ & no \\
\hline 5 & Windbigler & AC Windbigler & Ohio & Morrow & 40.69033 & -82.68222 & $34-117-20047$ & yes \\
\hline 6 & Palmer & J Palmer & Ohio & Richland & 40.64802 & -82.58955 & $34-139-20289$ & yes \\
\hline 7 & Lee & Edwin L Lee & Ohio & Coshocton & 40.32292 & -82.00095 & $34-031-22053$ & yes \\
\hline 8 & Marshall & WR Marshall & Ohio & Guernsey & 40.03672 & -81.72047 & $34-059-20782$ & yes \\
\hline 9 & Ullman & Robert Ullman & Ohio & Noble & 39.61067 & -81.34730 & $34-121-21278$ & yes \\
\hline 10 & Deem & Howard H Deem Et Ux & West Virginia & Wood & 39.08057 & -81.50795 & $47-107-00756$ & yes \\
\hline 11 & McCoy & McCoy Walter Et Al & West Virginia & Jackson & 38.73055 & -81.56944 & $47-035-01366$ & yes \\
\hline 12 & Gainer-Lee & Gainer-Lee & West Virginia & Calhoun & 38.87500 & -81.09760 & 47-013-02503 & no \\
\hline
\end{tabular}


Table 2. Formation groupings, model unit names, and ages at the depositional top of the model unit. Stratigraphic information is based on Ryder et al. (2004). Model unit ages are based on the formation ages defined in Ryder et al. (2004, Fig. 3), and on the time scale of Gradstein et al. (2004).

Age $\quad$ Model Age at Top of Unit (m.y.)

\section{Formations}

Model Unit Name

\begin{tabular}{|c|c|c|c|}
\hline Permian & 230 & Dunkard Gp & 'PERMIAN / TRIASSIC' \\
\hline Pennsylvanian & 299 & \begin{tabular}{|l|} 
Pottsville Gp \\
Undivided Strata
\end{tabular} & 'PENNSYLVANIAN' \\
\hline Mississippian & 318 & $\begin{array}{l}\text { Mauch Chunk Gp } \\
\text { Maxville Ls / Greenbrier Ls } \\
\text { Logan Fm / Cuyahoga Fm (Pocono Gp) / Pocono Gp } \\
\text { Big Injun ss (Pocono Gp) } \\
\text { Cuyahoga Fm (Pocono Gp) } \\
\text { Sunbury Sh } \\
\text { Berea Ss }\end{array}$ & 'MISSISSIPPIAN' \\
\hline Devonian & 360 & $\begin{array}{l}\text { Bedford Sh \& unnamed ss \& slts / Undivided Strata (sandy facies) } \\
\text { Undivided Strata (silty facies) } \\
\text { Cleveland Sh Mbr of Ohio Sh / Chagrin Sh Mbr of Ohio Sh / Ohio Sh / Undivided Strata } \\
\text { Three Lick Bed (Ohio Sh) } \\
\text { Huron Mbr (lower) of Ohio Sh } \\
\text { Java Fm }\end{array}$ & 'DEVONIAN - Ohio Shale' \\
\hline Devonian & 377 & $\begin{array}{l}\text { Angola Sh Mbr of West Falls Fm } \\
\text { Upper Olentangy Sh / Rhinestreet Sh Mbr of West Falls Fm } \\
\text { Cashaqua Sh Mbr of Sonyea Fm / Sonyea Fm } \\
\text { Middlesex Sh Mbr of Sonyea Fm } \\
\text { Gennessee Fm } \\
\text { Geneseo Sh Mbr of Genessee Fm } \\
\text { Tully Ls } \\
\text { Lower Olentangy Sh / Hamilton Gp } \\
\text { Delaware Ls / Marcellus Sh (Hamilton Gp) }\end{array}$ & 'DEVONIAN - lower shales' \\
\hline
\end{tabular}


Table 2 Cont.

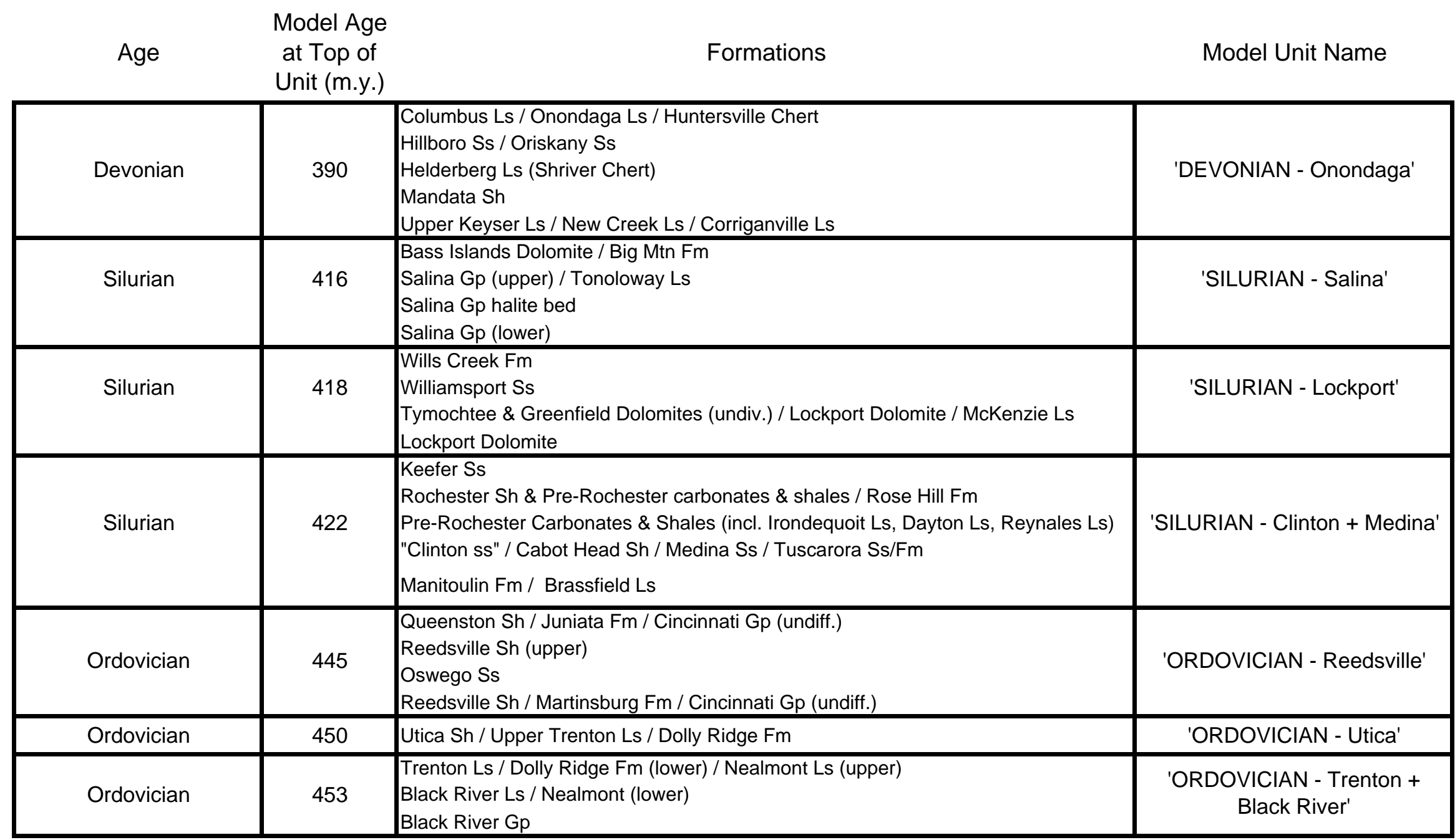


Table 2 Cont.

\begin{tabular}{|c|c|c|c|}
\hline Age & $\begin{array}{l}\text { Model Age } \\
\text { at Top of } \\
\text { Unit (m.y.) }\end{array}$ & Formations & Model Unit Name \\
\hline Ordovician - Cambrian & 461 & $\begin{array}{l}\text { Wells Creek Fm / Upper Beekmantown Gp / Row Park Ls } \\
\text { Upper Beekmantown Gp with ss (St Peter Ss equiv.) } \\
\text { Beekmantown Dolomite / Lower Beekmantown Gp } \\
\text { Rose Run Ss / Upper ss mbr of Copper Ridge Dolomite } \\
\text { Knox Dolomite (upper) / Copper Ridge Dolomite (upper) } \\
\text { "B" Zone / "B" Zone equiv. } \\
\text { Knox Dolomite (lower) / Copper Ridge Dolomite (lower) } \\
\text { Lower ss mbr of Copper Ridge Dolomite }\end{array}$ & $\begin{array}{c}\text { 'ORDOVICIAN / } \\
\text { CAMBRIAN - Beekmantown }\end{array}$ \\
\hline Cambrian & 493 & $\begin{array}{l}\text { Kerbel Dolomite / Conasauga Fm/Gp (unnamed sh mbr, Nolichucky Sh equiv.) } \\
\text { Conasauga Fm } \\
\text { "Rome Fm" (upper) / Unnamed dolo mbr of Maryville Ls (Conasauga Gp) / Elbrook Dolomite } \\
\text { "Rome ss" } \\
\text { "Rome Fm" (lower) } \\
\text { "Lower Rome ss" } \\
\text { Mt. Simon Ss / Unnamed ss mbr of Maryville Ls (Conasauga Gp) } \\
\end{array}$ & CAMBRIAN - Conasauga \\
\hline Cambrian & 500 & $\begin{array}{l}\text { Rome Fm / Unnamed Is mbr of Maryville Ls (Conasauga Gp) } \\
\text { Rogersville Sh (Conasauga Gp) } \\
\text { Rutledge Ls (Conasauga Gp) } \\
\text { Pumpkin Valley Sh (Conasauga Gp) } \\
\text { Unnamed Is mbr of Rome Fm } \\
\text { Unnamed ss \& sh mbrs of Rome Fm } \\
\text { Shady Ls } \\
\text { Basal ss }\end{array}$ & CAMBRIAN - Rome trough' \\
\hline Precambrian & 520 & Igneous/metamorphic basement rocks & 'Basement' \\
\hline
\end{tabular}


Table 3. Compositions of model units, given as fractions of individual lithologies. The fractions sum to one within each model unit.

Model Unit

Lithology

\begin{tabular}{|c|c|c|c|c|c|c|c|}
\hline & Sandstone & Siltstone & Shale & $\begin{array}{l}\text { Black } \\
\text { Shale }\end{array}$ & Coal & Carbonate & Anhydrite \\
\hline 'PERMIAN / TRIASSIC' & 0.246 & 0.225 & 0.519 & 0 & 0.005 & 0.005 & 0 \\
\hline 'PENNSYLVANIAN' & 0.261 & 0.203 & 0.429 & 0.071 & 0.021 & 0.015 & 0 \\
\hline 'MISSISSIPPIAN' & 0.167 & 0.291 & 0.435 & 0.061 & 0.006 & 0.040 & 0 \\
\hline 'DEVONIAN - Ohio Shale' & 0.028 & 0.231 & 0.359 & 0.378 & 0.004 & 0 & 0 \\
\hline 'DEVONIAN - lower shales' & 0.007 & 0.070 & 0.314 & 0.444 & 0.001 & 0.164 & 0 \\
\hline 'DEVONIAN - Onondaga etc' & 0.049 & 0.039 & 0.036 & 0.073 & 0 & 0.802 & 0.001 \\
\hline 'SILURIAN - Salina' & 0.010 & 0.030 & 0.075 & 0.015 & 0 & 0.640 & 0.230 \\
\hline 'SILURIAN - Lockport' & 0.017 & 0.008 & 0.052 & 0.040 & 0 & 0.850 & 0.033 \\
\hline 'SILURIAN - Clinton + Medina' & 0.153 & 0.173 & 0.333 & 0.014 & 0 & 0.327 & 0 \\
\hline 'ORDOVICIAN - Queenston' & 0 & 0.116 & 0.729 & 0.033 & 0 & 0.122 & 0 \\
\hline 'ORDOVICIAN - Utica' & 0 & 0.003 & 0.373 & 0.413 & 0 & 0.211 & 0 \\
\hline 'ORDOVICIAN - Trenton + Black River' & 0.001 & 0 & 0.039 & 0.017 & 0 & 0.943 & 0 \\
\hline $\begin{array}{l}\text { 'ORDOVICIAN /CAMBRIAN - } \\
\text { Beekmantown + Knox' }\end{array}$ & 0.052 & 0.030 & 0.015 & 0.006 & 0 & 0.897 & 0 \\
\hline 'CAMBRIAN - Conasauga & 0.263 & 0.045 & 0.068 & 0.003 & 0 & 0.621 & 0 \\
\hline 'CAMBRIAN - Rome Trough' & 0.300 & 0.207 & 0.185 & 0.020 & 0 & 0.288 & 0 \\
\hline
\end{tabular}


Table 4. Parameters and functions used in determining porosity and thermal conductivity for individual lithologies. See text for discussion.

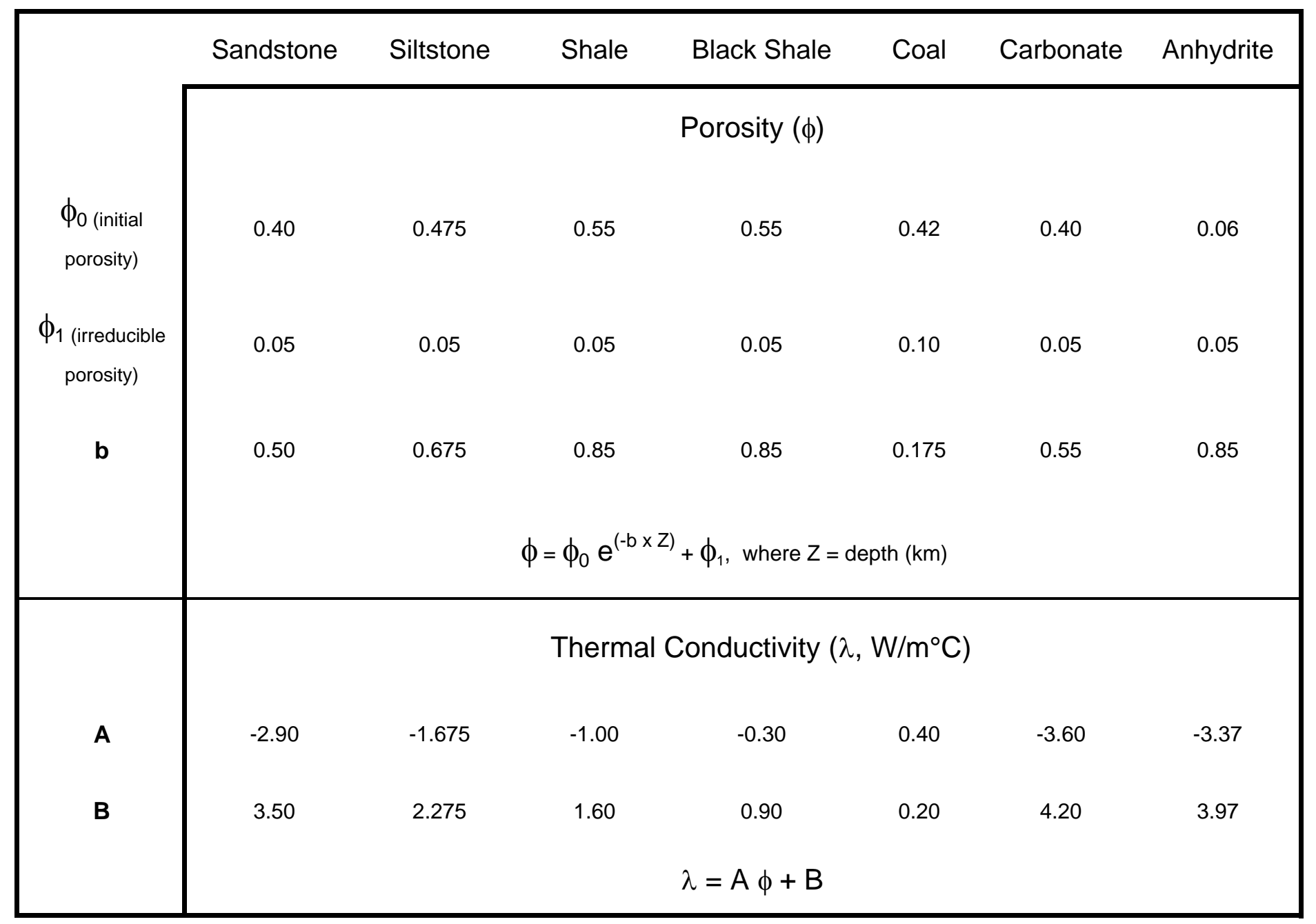


Table 5. Reconstructed thickness of eroded sedimentary section. The amounts shown were added to the Silurian - Permian/Triassic model units, and subsequently removed ('eroded') , leaving present day, measured stratigraphic thicknesses.

\begin{tabular}{|c|c|c|c|c|c|c|c|}
\hline \multirow[b]{2}{*}{ Well No. } & \multicolumn{7}{|c|}{ Reconstructed Section, ft (m) } \\
\hline & Well Name & Silurian & Devonian & Mississippian & Pennsylvanian & Permian / Triassic & Total \\
\hline 1 & Carter & $100(30)$ & $130(40)$ & $100(30)$ & $700(213)$ & 0 & 1030 \\
\hline 2 & Kerbel & $150(46)$ & $225(69)$ & $150(46)$ & $800(244)$ & 0 & 1325 \\
\hline 3 & Asphalt & $200(61)$ & $320(98)$ & $200(61)$ & $900(274)$ & 0 & 1620 \\
\hline 4 & Leonhardt & 0 & 0 & $300(91)$ & $1000(305)$ & 0 & 1300 \\
\hline 5 & Windbigler & 0 & 0 & 0 & $1100(335)$ & 0 & 1100 \\
\hline 6 & Palmer & 0 & 0 & 0 & $1200(366)$ & 0 & 1200 \\
\hline 7 & Lee & 0 & 0 & 0 & $1260(384)$ & 3994 (1218) & 5254 (1602) \\
\hline 8 & Marshall & 0 & 0 & 0 & 572 (174) & $4200(1280)$ & 4772 (1455) \\
\hline 9 & Ullman & 0 & 0 & 0 & 0 & 4950 (1509) & 4950 (1509) \\
\hline 10 & Deem & 0 & 0 & 0 & 0 & $5346(1630)$ & $5346(1630)$ \\
\hline 11 & McCoy & 0 & 0 & 0 & 0 & 6070 (1851) & $6070(1851)$ \\
\hline 12 & Gainer-Lee & 0 & 0 & 0 & 0 & 7200 (2195) & 7200 (2195) \\
\hline
\end{tabular}




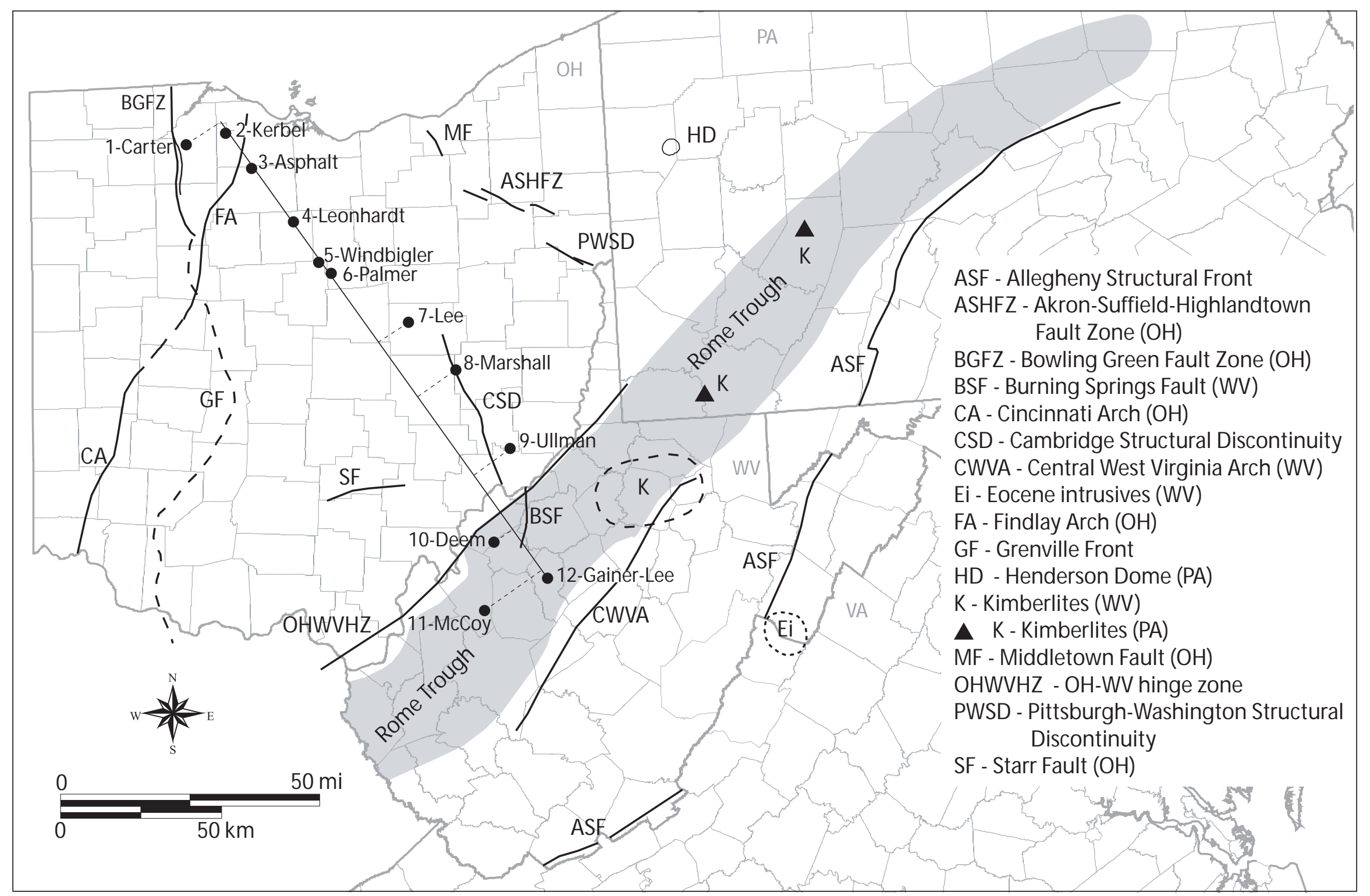

Figure 1. Locations of some of the major structural and geologic features in the vicinity of the model cross section. References for structural features are compiled in Repetski et al. (2002; in review; manuscript in prep.). Numbered black dots refer to wells used in the model (see Table 1). 


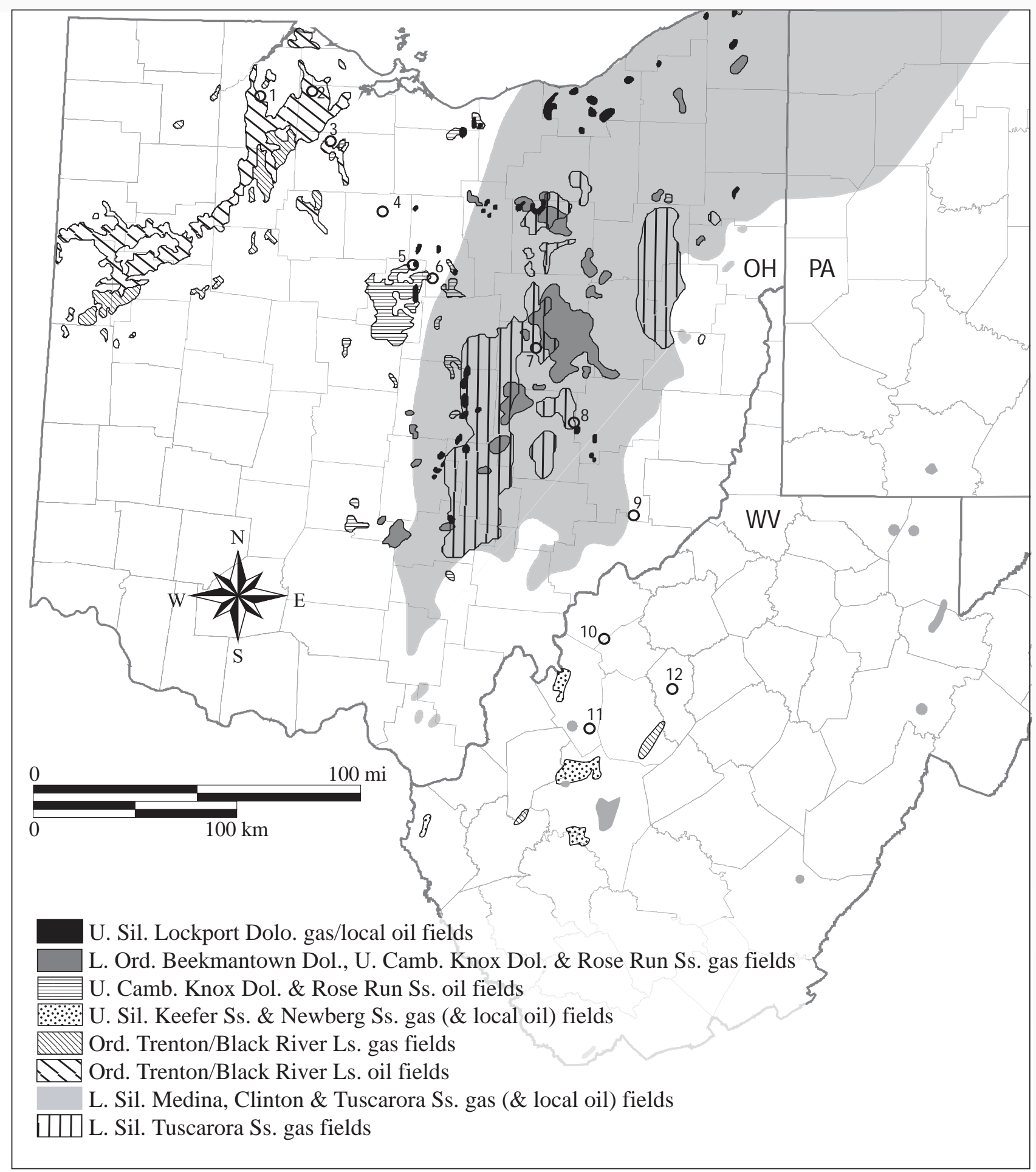

Figure 2. Oil and gas fields in Silurian, Ordovician, and Cambrian strata in the central Appalachian basin. Numbered circles refer to wells used in the model cross section (Table 1). References for oil and gas field locations are compiled in Repetski et al. (in review; manuscript in prep.). 
NW

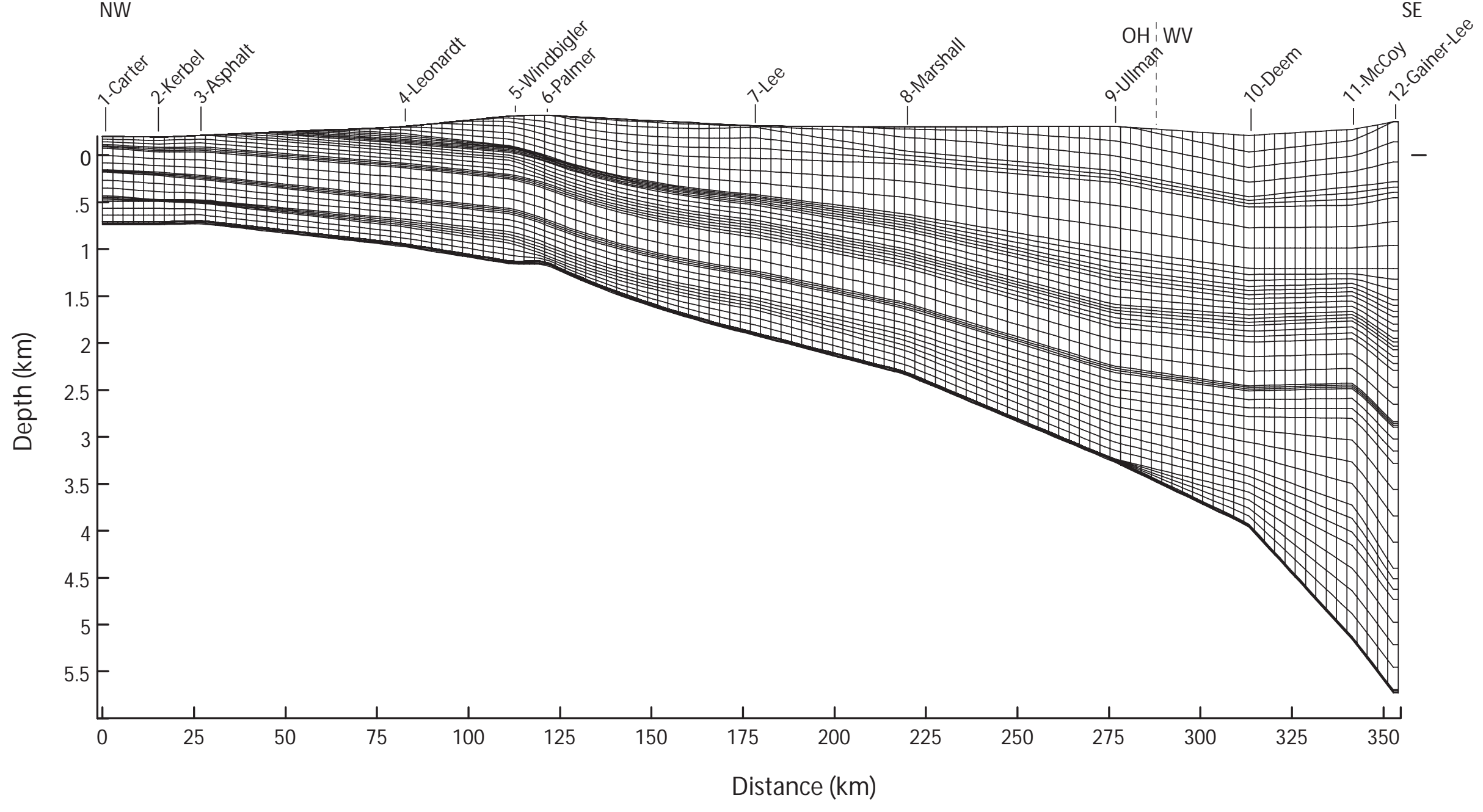

Figure 3. Grid used in modeling the cross section. The length of the cross section is $354 \mathrm{~km}$. Cell widths are $2.8 \mathrm{~km}$ and cell heights are variable, with a maximum of $280 \mathrm{~m}$ and a minimum of three nodes per model unit. Locations of wells used in constructing the model are indicated along the top of the cross section. 


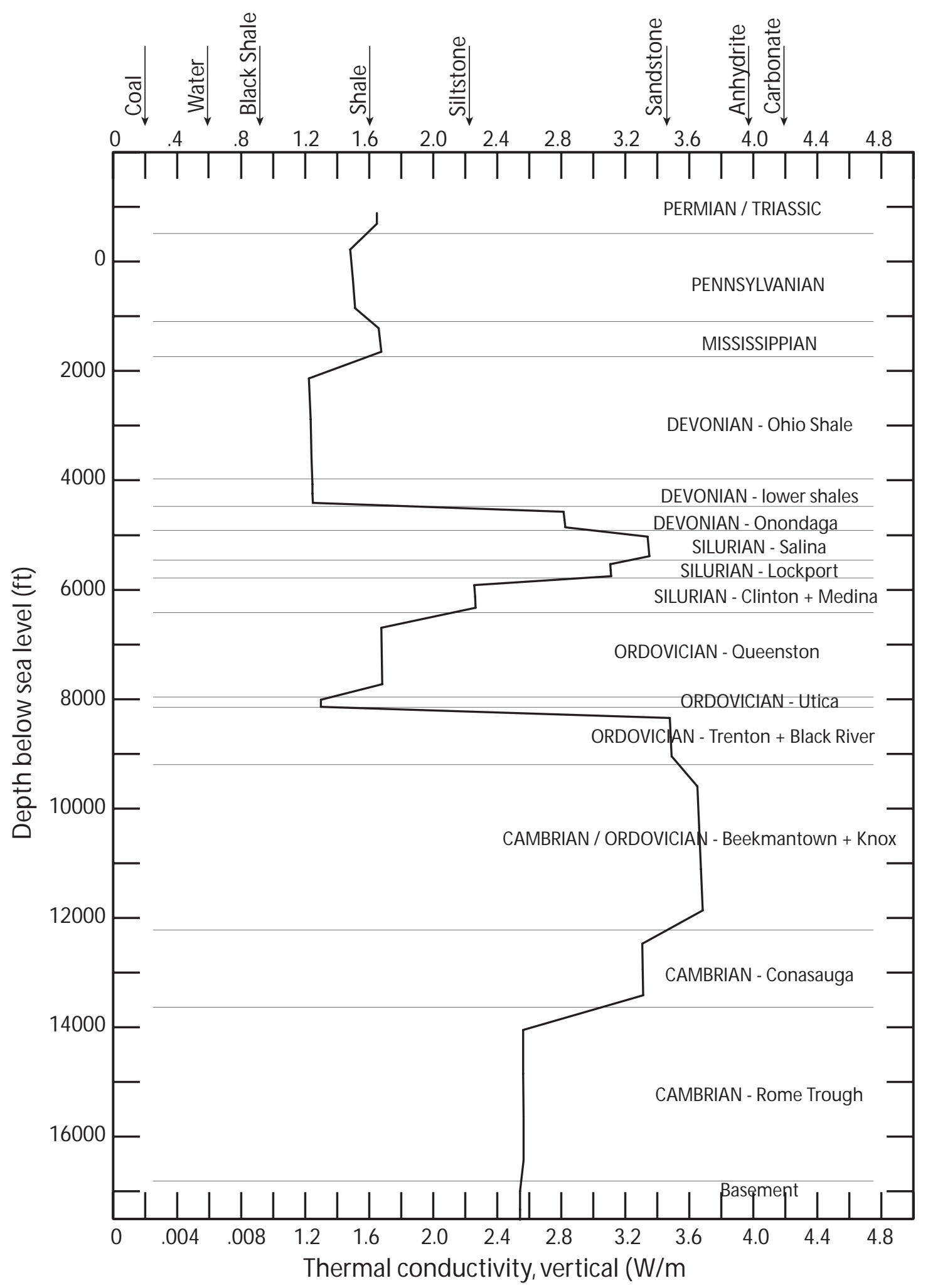

Figure 4. Vertical, bulk thermal conductivity profile of model units in the McCoy well (well \#11, at $342 \mathrm{~km}$ on the cross section). Bulk conductivities are determined from the fractions of each component lithology and water in the unit. Variations in conductivity between the units result from differences in lithology (see Table 2) and in degree of compaction. Conductivities of water and of the end-member lithologies at zero porosity are shown for reference along the top axis. 


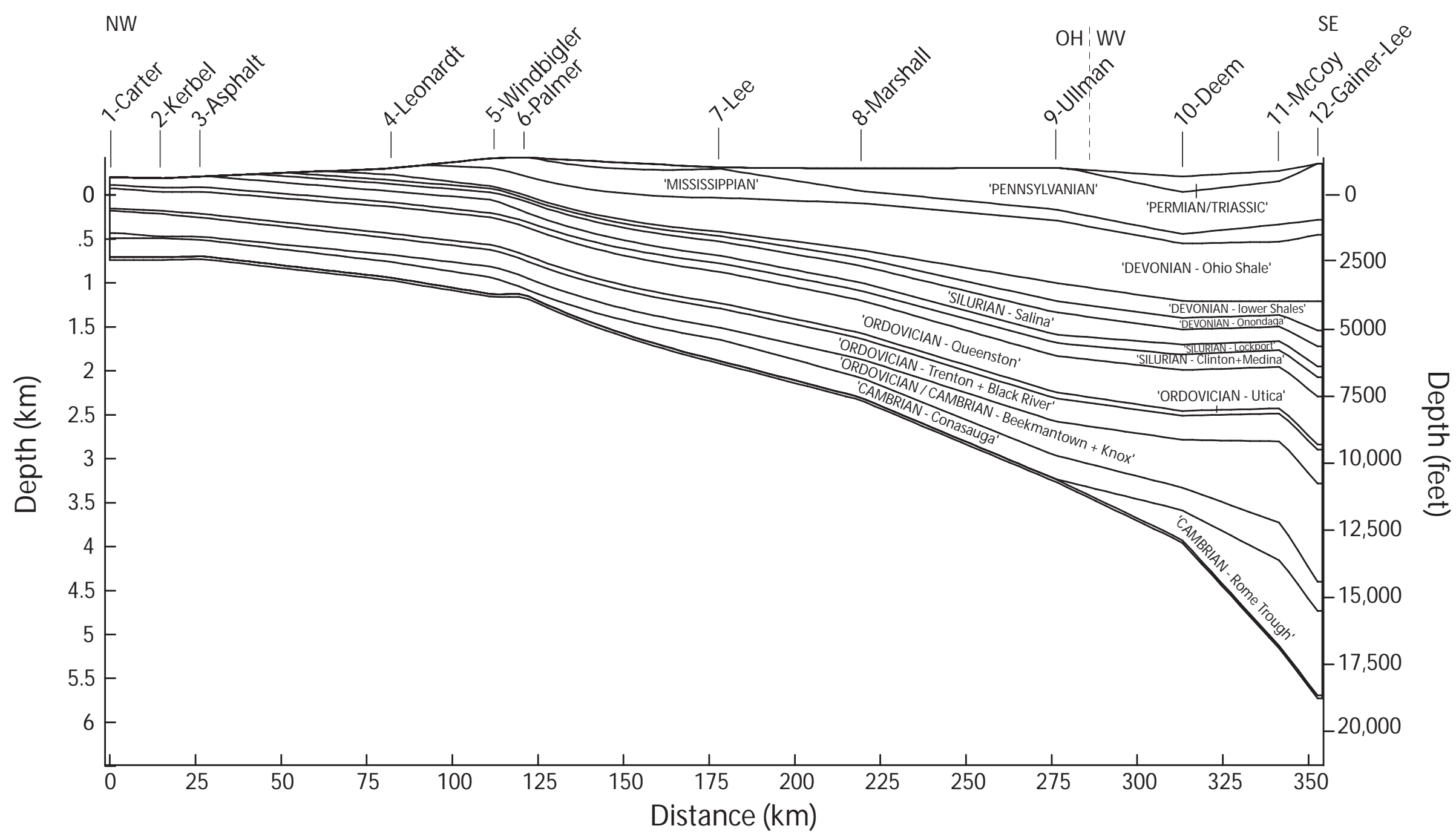

Figure 5. Model cross section showing present day topography, stratigraphy, model units, and well locations. 


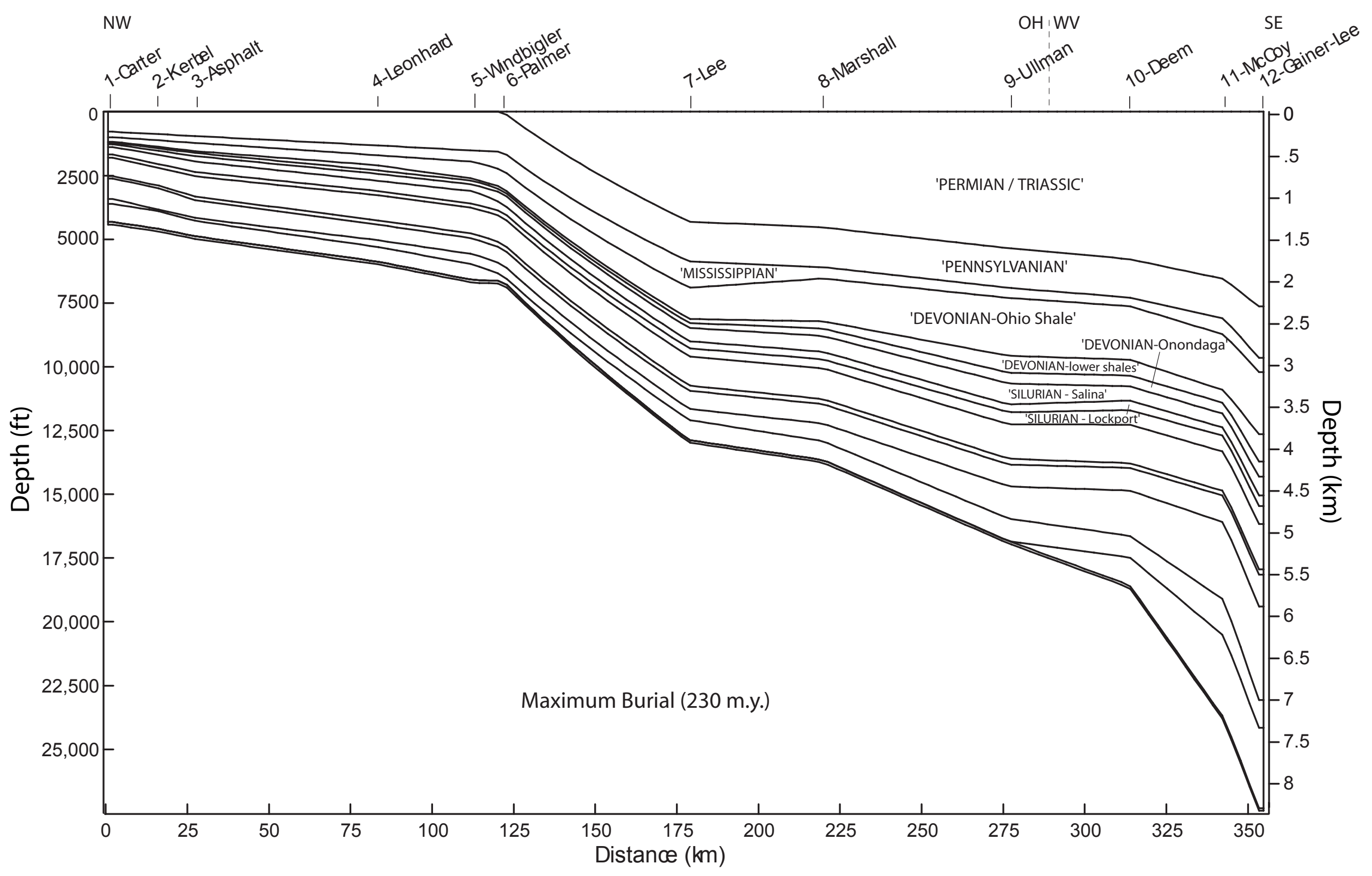

Figure 6. Model cross section at maximum burial (230 m.y.). The dimensions of the 'Permian / Triassic' model unit were adjusted so as to match measured thermal maturities. The 'Pennsylvanian' through 'Silurian - Lockport' units were restored to preserve continuous, but westward thinning strata along the cross section. 


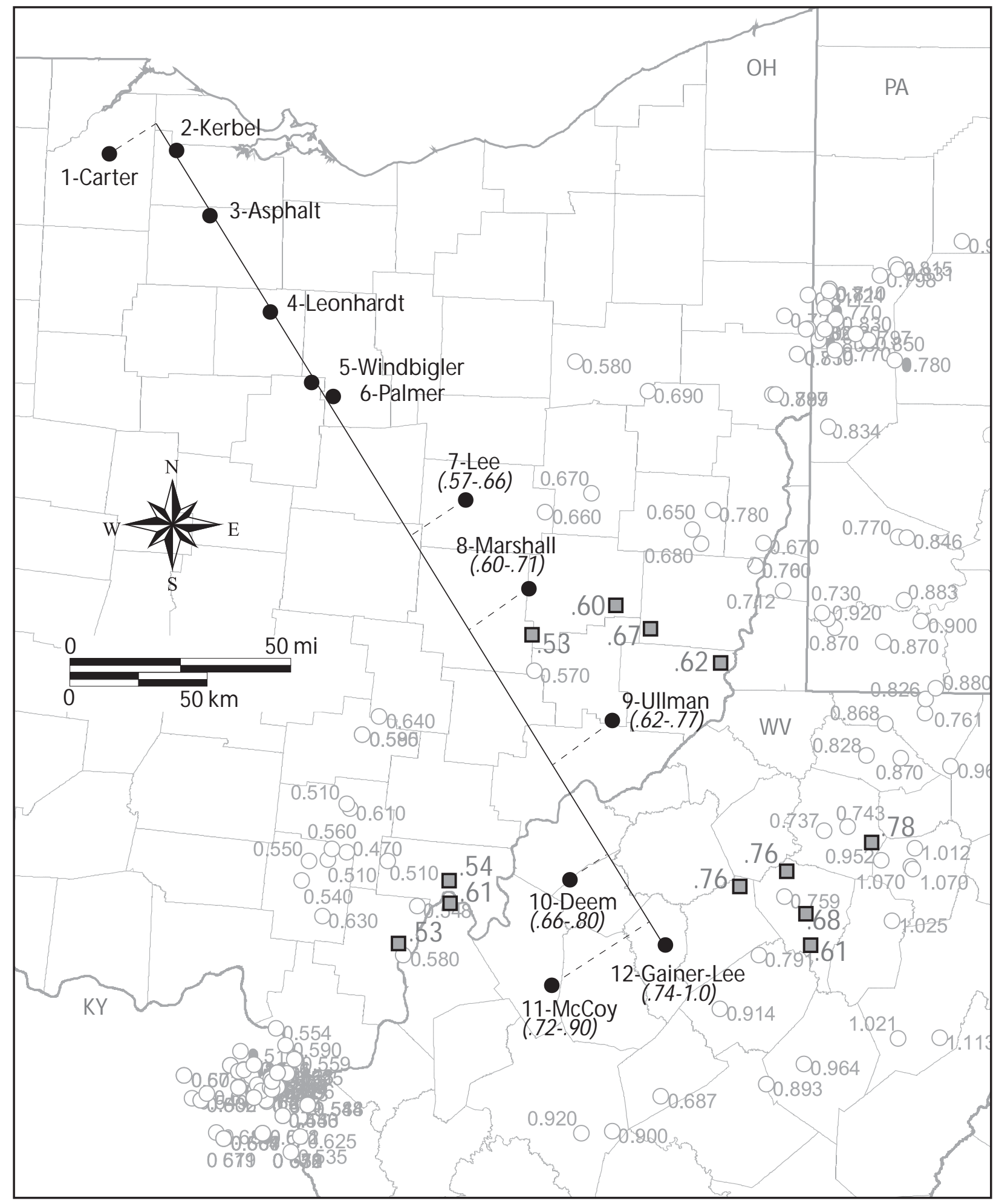

Figure 7. Sample sites and measured vitrinite reflectance (Ro\%) values in Pennsylvanian coals (solid squares: Chyi et al., 1987; open circles: Ruppert, USGS unpub. data). Solid black dots indicate wells used in the model. Ro\% values predicted by the model at each well are shown in parentheses below the well name. 


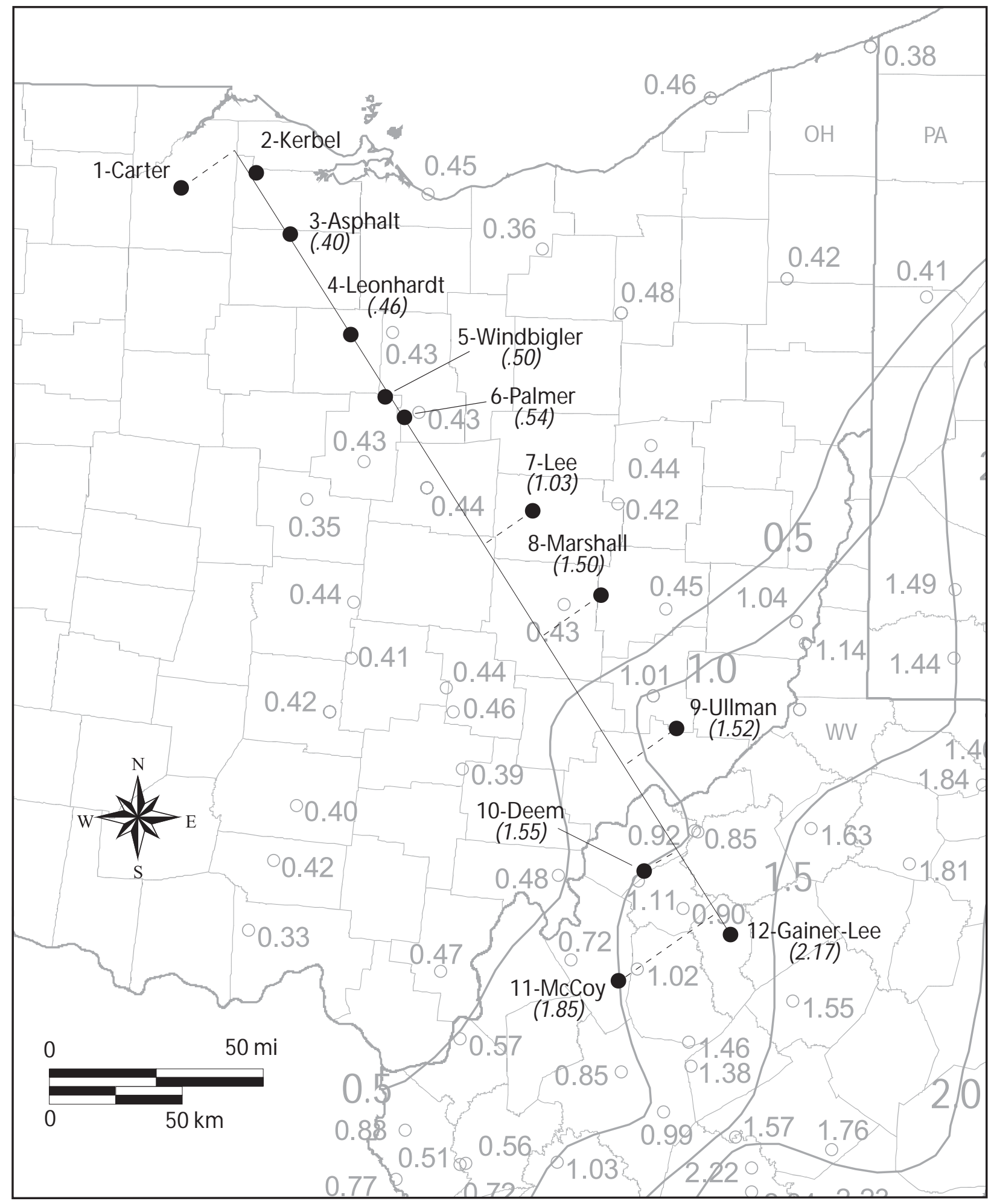

Figure 8. Sample sites (open circles) and measured vitrinite reflectance (Ro\%) values for dispersed vitrinite in Middle and Upper Devonian shales. Data and contours are from Repetski et al. (2002; 2004; in review). Solid black dots indicate wells used in the model. Ro\% values predicted by the model at each well are shown in parentheses below the well name. 


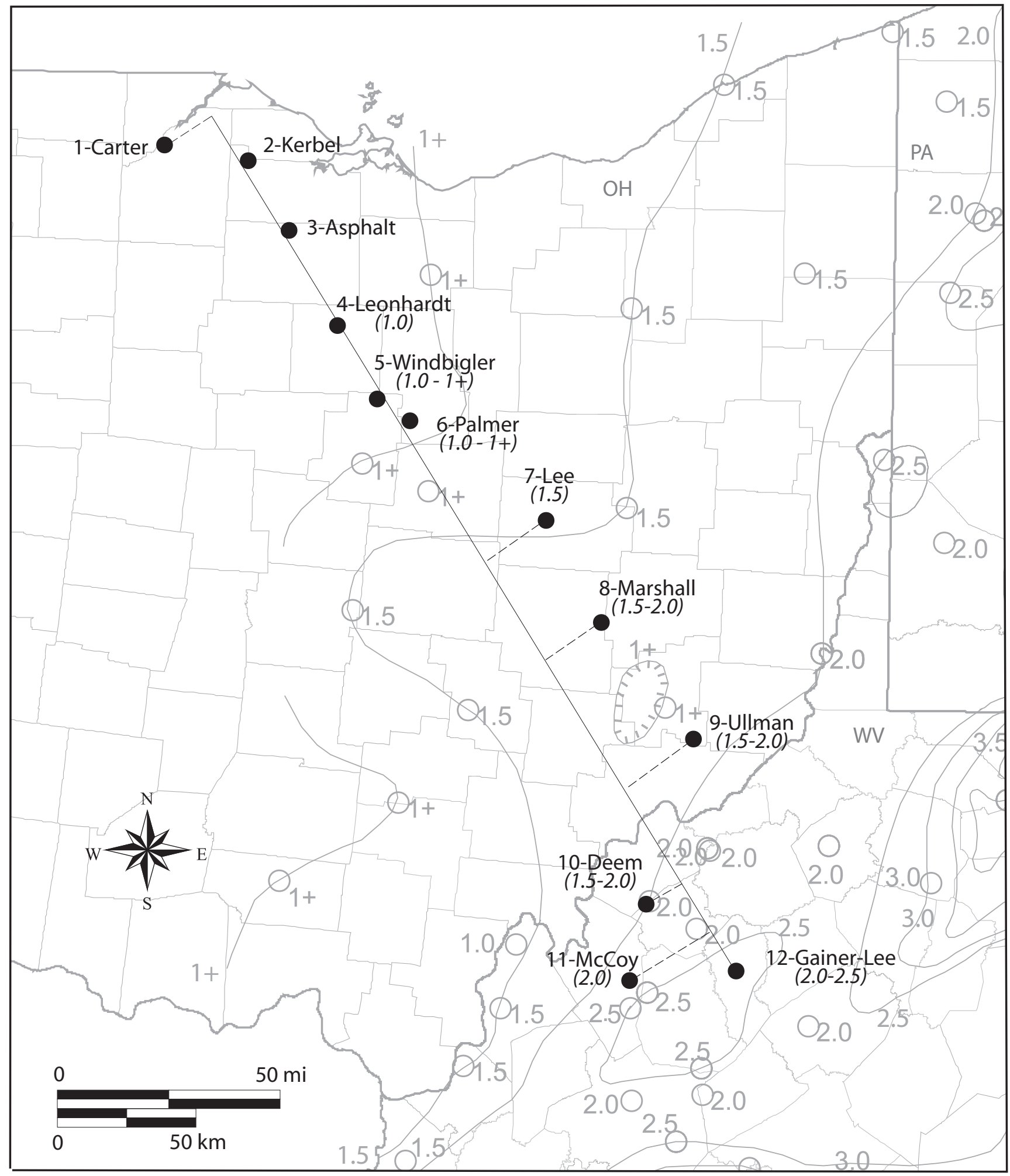

Figure 9. Sample sites (open circles) and measured conodont CAI values in the Devonian Onondaga Limestone. Data and contours from Repetski et al. (2002; 2004; in review). Solid black dots indicate wells used in the model. Ro\% values predicted by the model and translated to conodont CAI values at each well are shown in parentheses below the well name. 


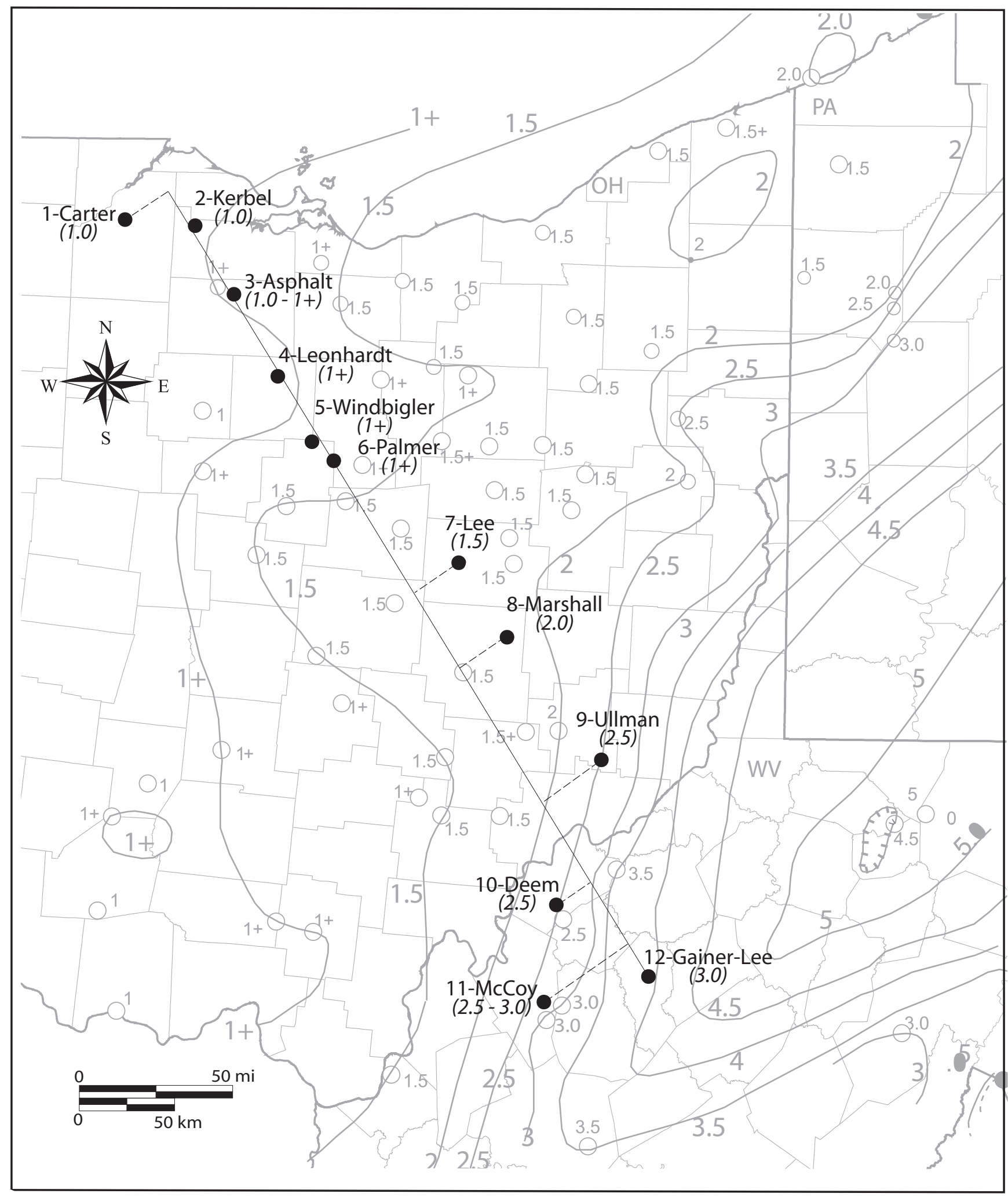

Figure 10. Sample sites (open circles) and measured conodont CAI values in the Ordovician Trenton/Black River Limestone. Data and contours are from Repetski et al. (2002; 2004; in review; USGS unpub. data). Solid black dots indicate wells used in the model. Ro\% values predicted by the model and translated to conodont CAI values at each well are shown in parentheses below the well name. 


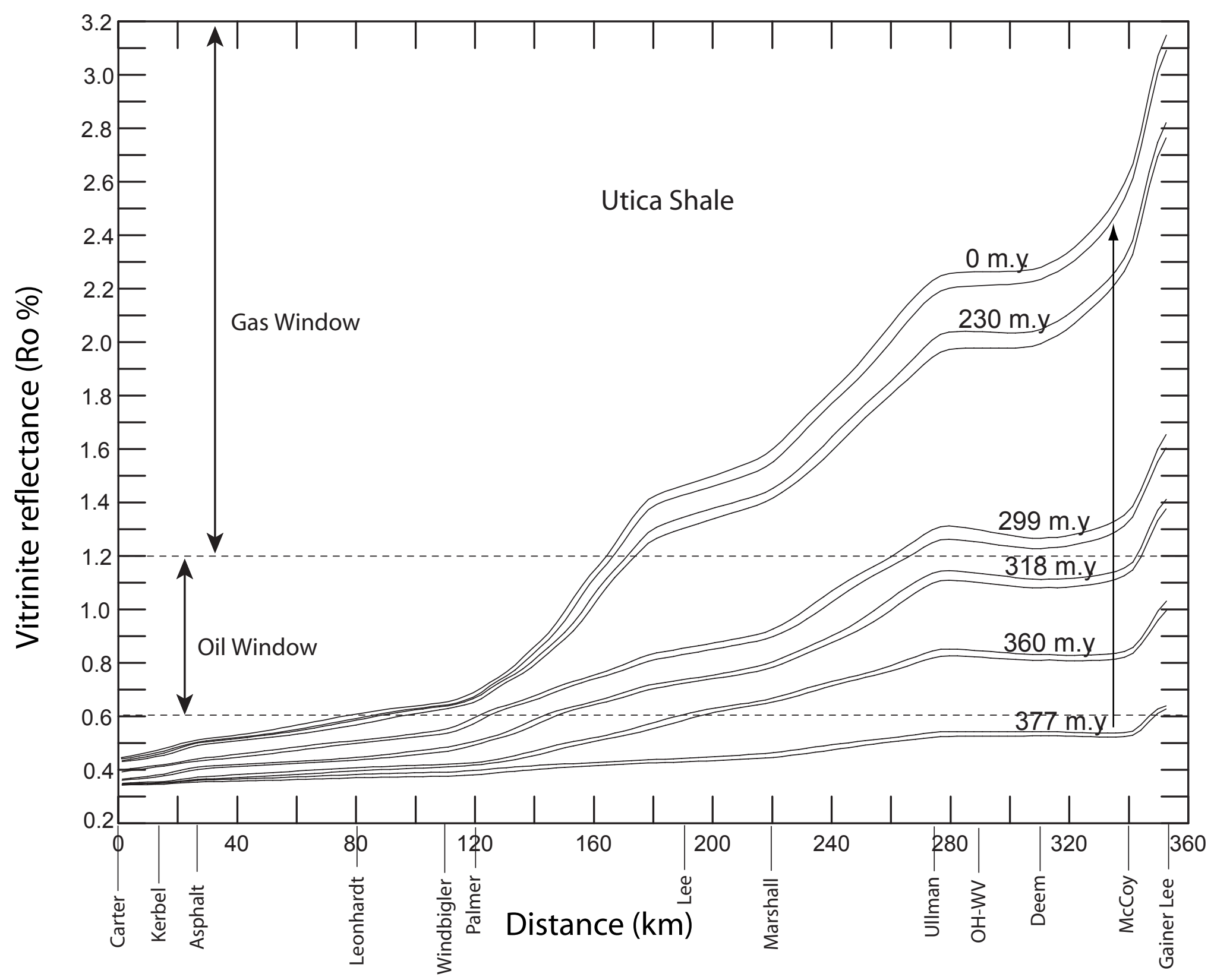

Figure 11. Model-predicted vitrinite reflectance (Ro \%) profiles along the cross section for the top and base of the 'Ordovician - Utica' model unit at six time horizons. Positions of wells on the cross section are shown along the axis. 


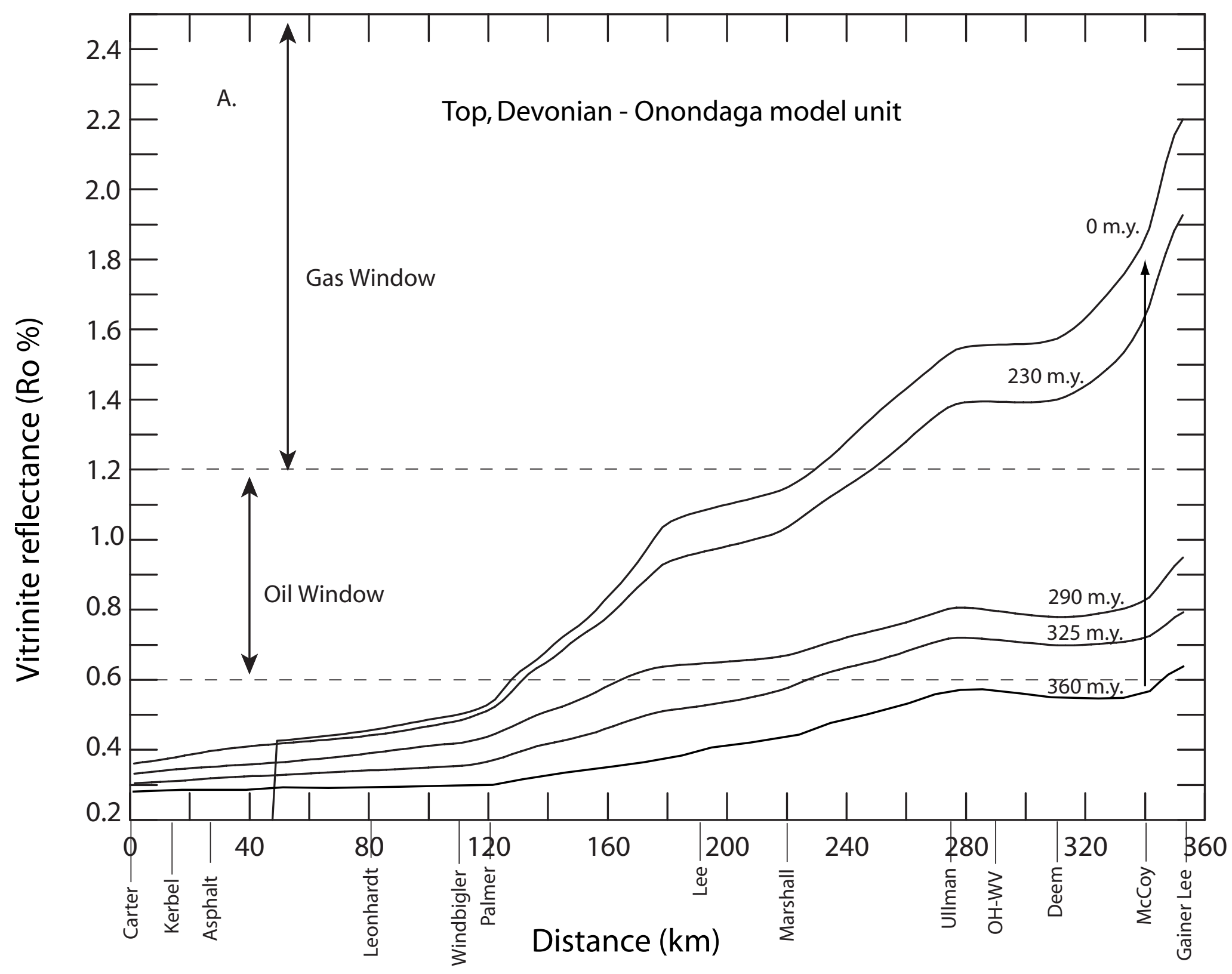

Figure 12A. Model-predicted vitrinite reflectance (Ro\%) profiles along the cross section for the top of the 'Devonian Onondaga' model unit (i.e., the base of Devonian shales) at five time horizons. Positions of wells on the cross section are shown along the distance axis. 


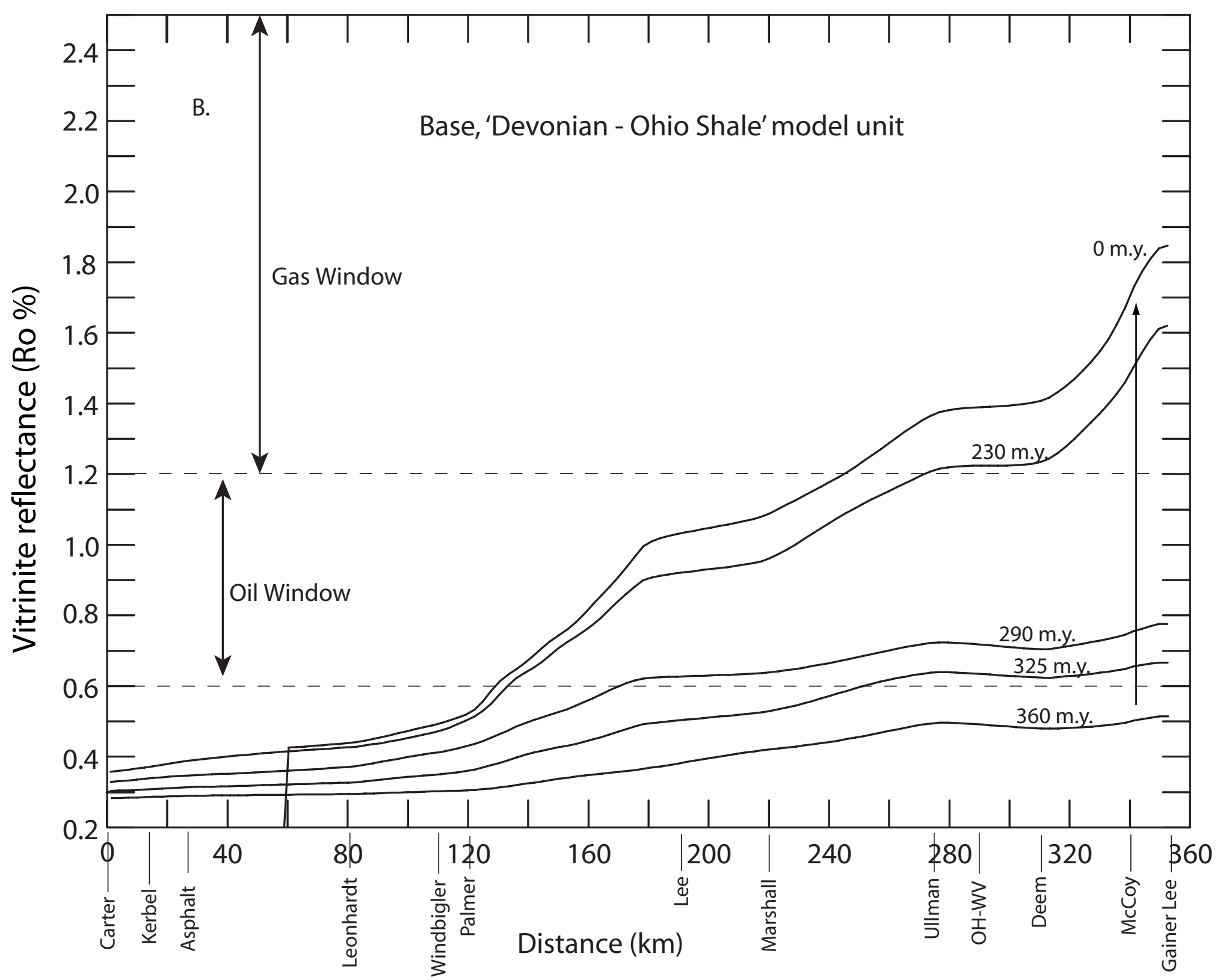

Figure 12B. Model-predicted vitrinite reflectance (Ro\%) profiles along the cross section for the base of the 'Devonian - Ohio Shale' model unit at five time horizons. Positions of wells on the cross section are shown along the distance axis. 


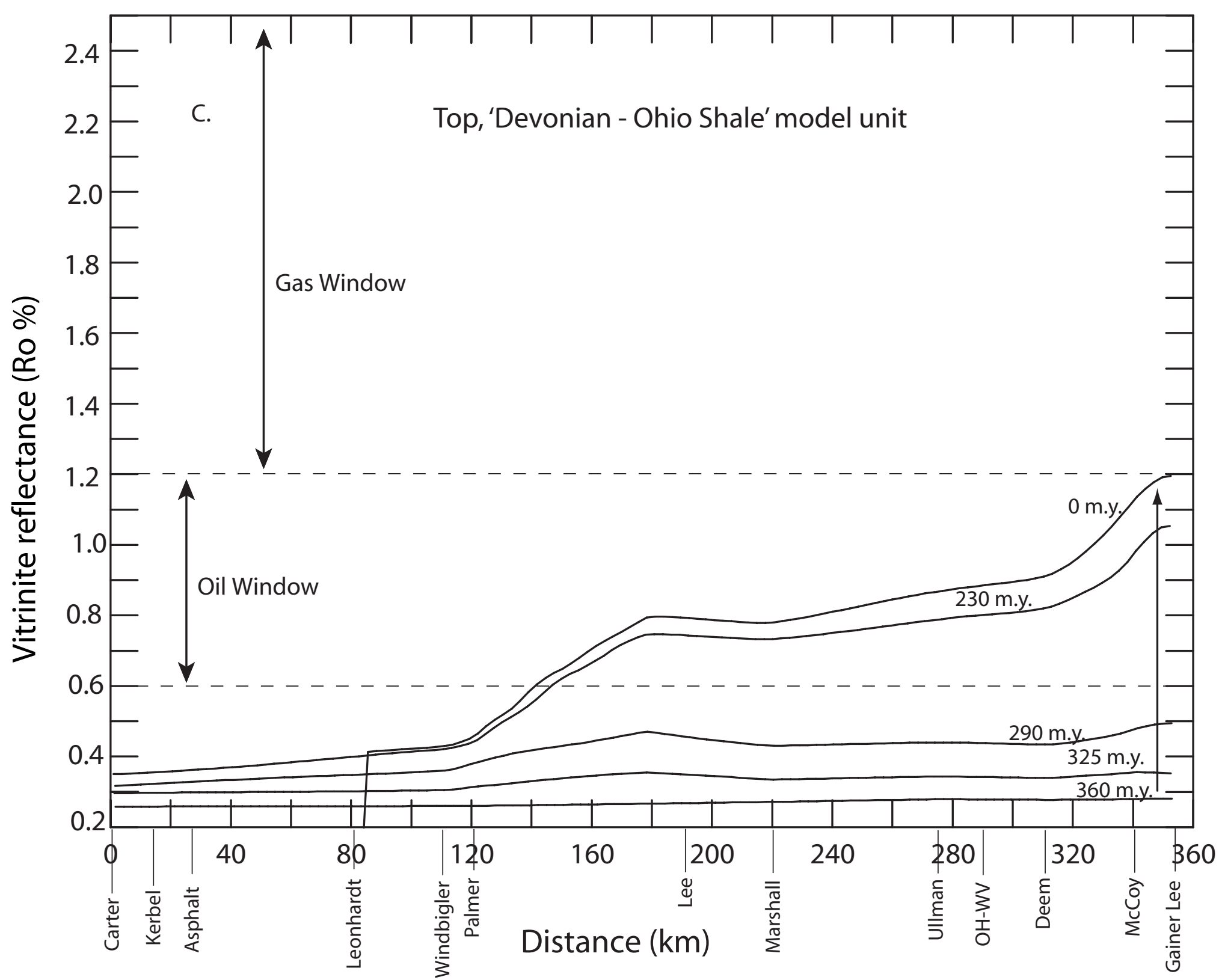

Figure 12C. Model-predicted vitrinite reflectance (Ro\%) profiles along the cross section for the top of the 'Devonian Ohio Shale' model unit at five time horizons. Positions of wells on the cross section are shown along the distance axis. 


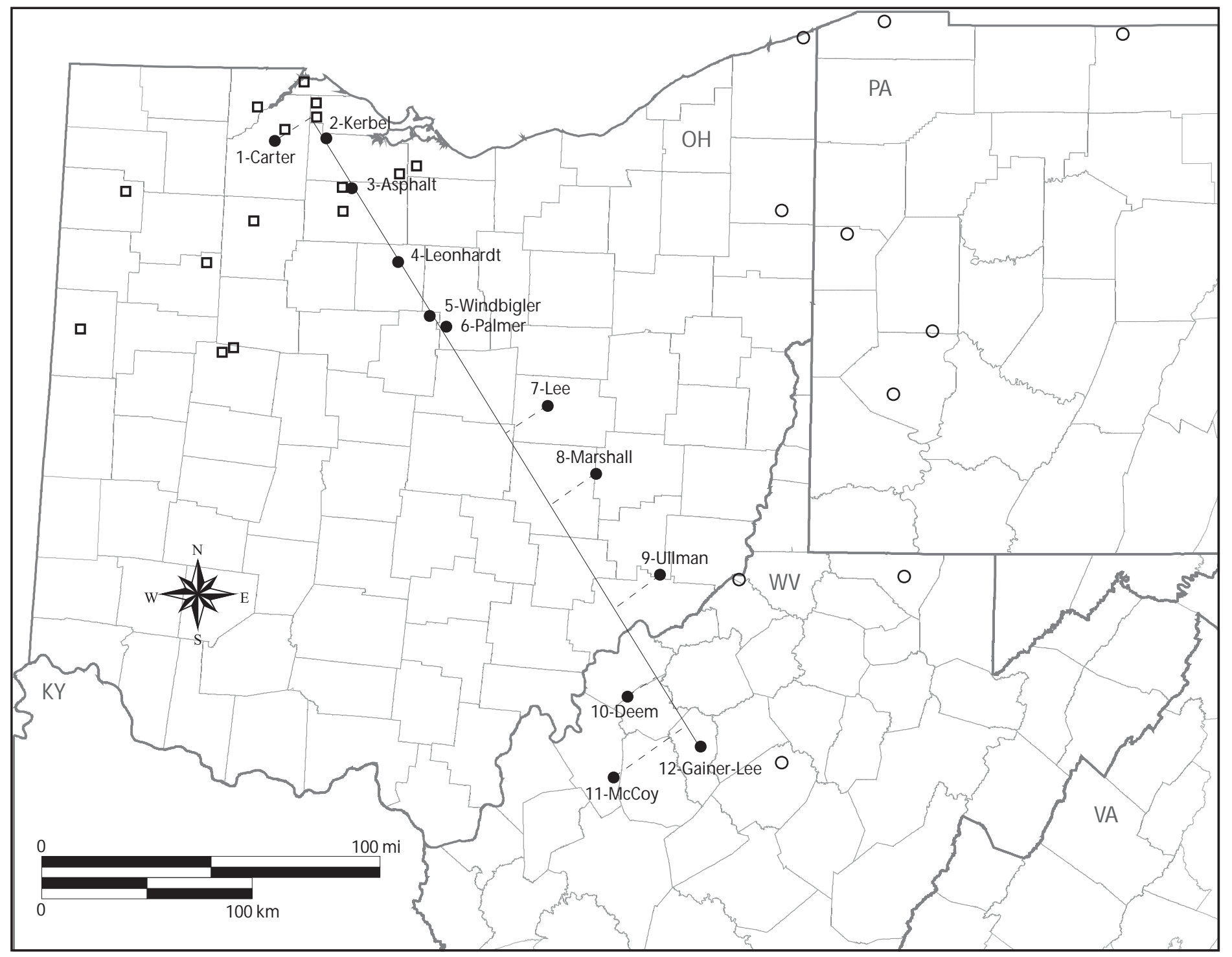

Figure 13. Sample sites for two fluid inclusion studies from the literature. Open circles are sites from Evans (1995); open squares are sites from Carlson (1994). Homogenization temperature ranges from these studies are shown in Figures 14A, B and 15. Solid black dots indicate wells used in this study. 


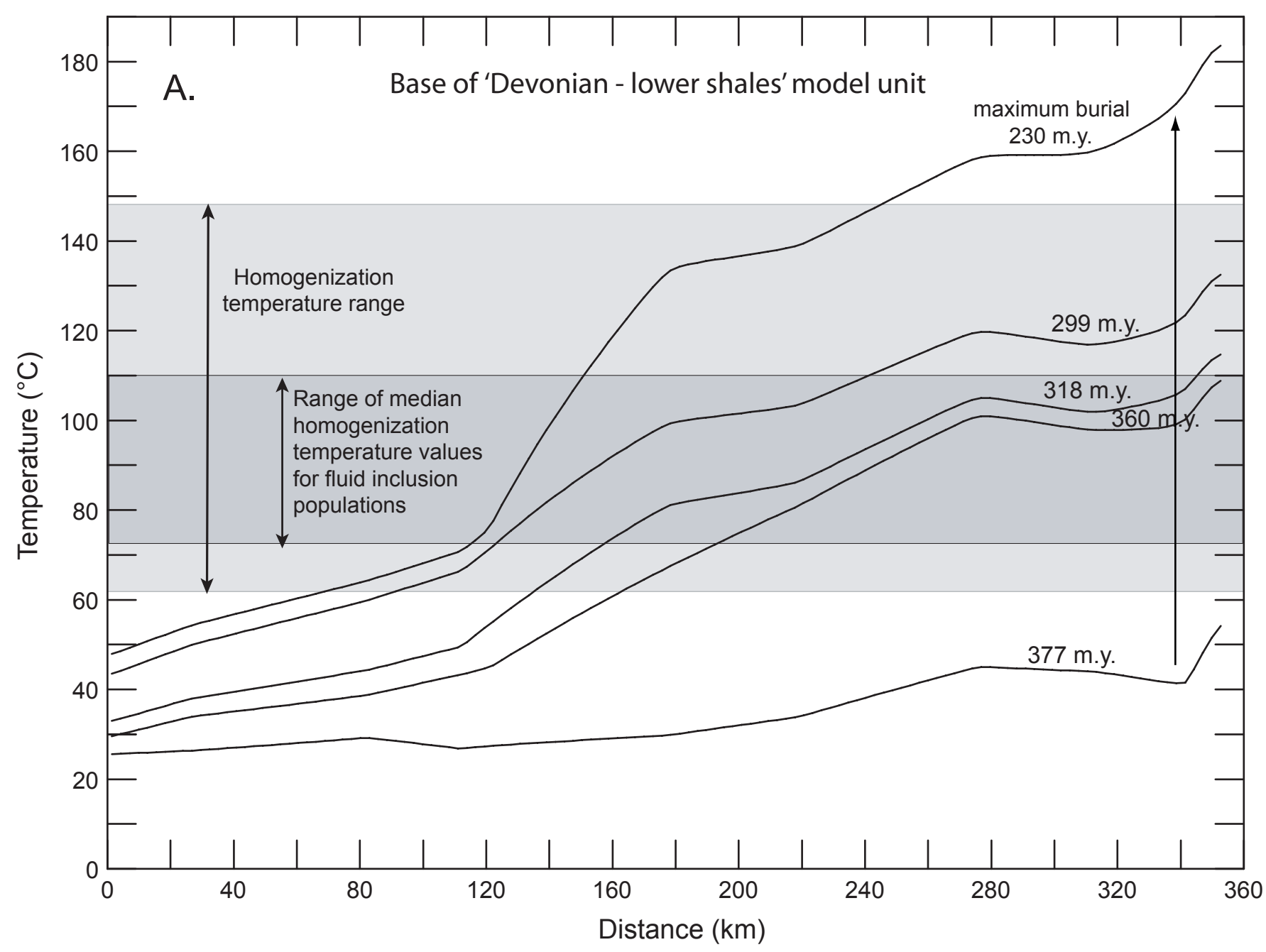

Figure 14A. Model-predicted temperature profiles with distance along the cross section at selected times for the base of the 'Devonian - lower shales' model unit, equivalent to the Devonian Marcellus Shale. Temperatures increase with time and burial depth from initial deposition (377 m.y.) to maximum burial (230 m.y.). The gray bands indicate ranges of fluid inclusion temperatures for epigenetic, vein-hosted minerals in the Marcellus Shale or its equivalent (Evans,1995). Model temperatures match the measured temperature ranges over a wide geographic region and over a wide time interval. 


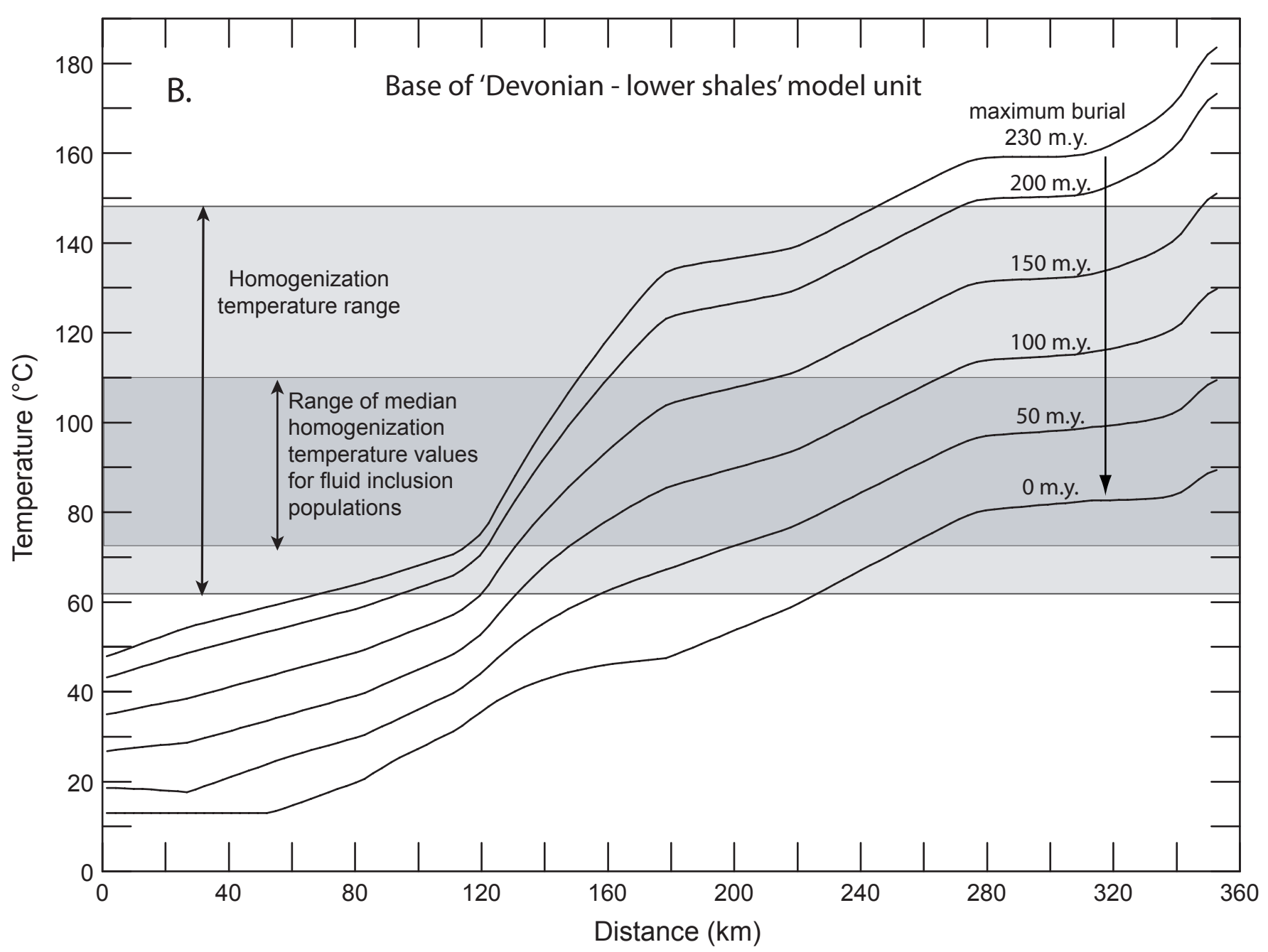

Figure 14B. Model-predicted temperature profiles with distance along the cross section at selected times for the base of the 'Devonian - lower shales' model unit, equivalent to the Devonian Marcellus Shale. Temperatures decrease with progressive erosion from maximum burial (230 m.y.) to present day (0 m.y.). The gray bands indicate ranges of fluid inclusion temperatures for epigenetic, vein-hosted minerals in the Marcellus Shale or its equivalent (Evans,1995). Model temperatures match the measured temperature ranges over a wide geographic region and over a wide time interval. 


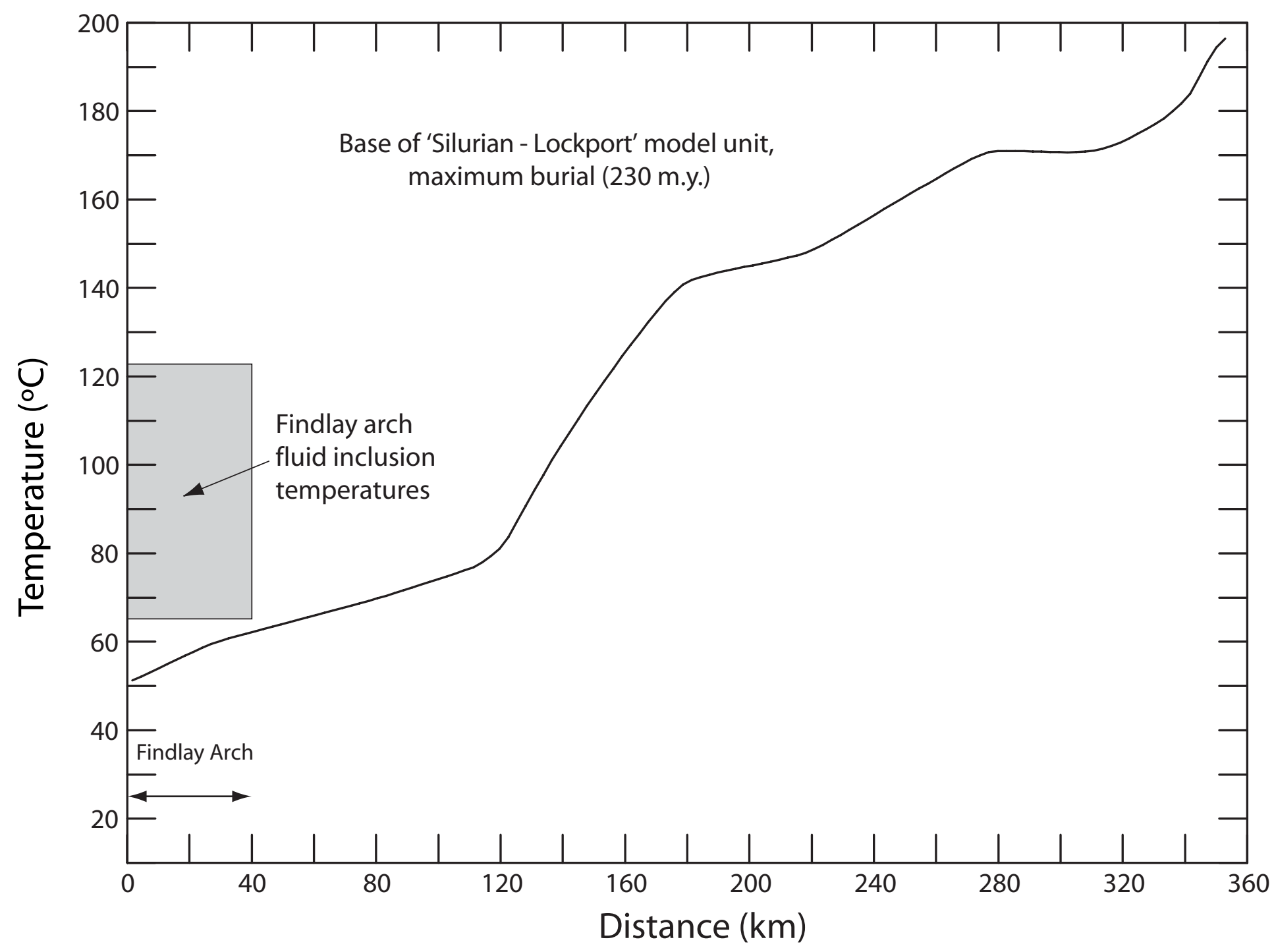

Figure 15. Model temperature profile along the cross secton for the base of the Silurian Lockport Dolomite at maximum burial (230 m.y.). The gray box indicates the range in the medians of fluid inclusion temperature populations on the Findlay arch (Carlson, 1994). Burial temperatures predicted by model are too low to account for the fluid inclusion temperatures. 